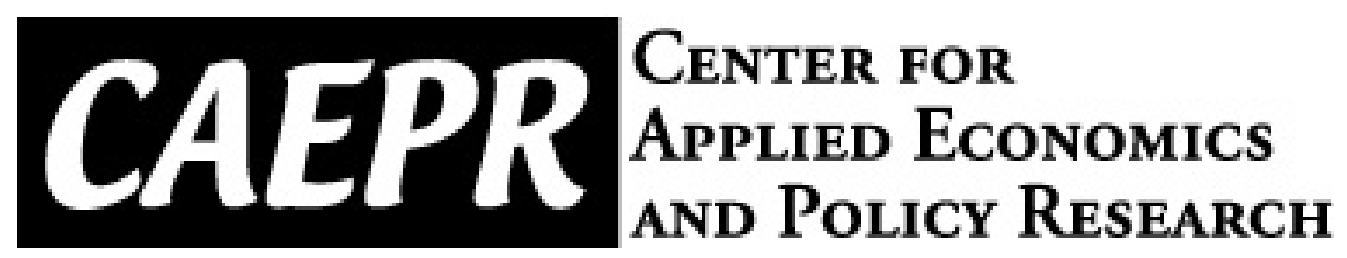

CAEPR Working Paper

\#006-2010

\title{
WHEN DOES GOVERNMENT DEBT CROWD OUT INVESTMENT?
}

\author{
Nora Traum \\ Indiana University \\ Shu-Chun Yang \\ Congressional Budget Office
}

May 1, 2010

This paper can be downloaded without charge from the Social Science Research Network electronic library at: http://ssrn.com/abstract=1611196.

The Center for Applied Economics and Policy Research resides in the Department of Economics at Indiana University Bloomington. CAEPR can be found on the Internet at:

http://www.indiana.edu/ caepr. CAEPR can be reached via email at caepr@indiana.edu or via phone at 812-855-4050.

(C2008 by NAME. All rights reserved. Short sections of text, not to exceed two paragraphs, may be quoted without explicit permission provided that full credit, including $₫$ notice, is given to the source. 


\title{
WHEN DOES GOVERNMENT DEBT CROWD OUT INVESTMENT?
}

\author{
NORA TRAUM AND SHU-CHUN S. YANG
}

\begin{abstract}
We examine when government debt crowds out investment for the U.S. economy using an estimated New Keynesian model with a detailed fiscal specification. The estimation accounts for the interaction between monetary and fiscal policies. Whether private investment is crowded in or out in the short term depends on the fiscal or monetary shock that triggers a debt expansion: higher debt can crowd in investment despite a higher real interest rate for a reduction in capital tax rates or an increase in productive government investment. Contrary to the conventional view of crowding out, no systematic relationship among debt, the real interest rate, and investment exists. This result offers an explanation as to why empirical studies that have focused on the reduced-form relationship between interest rates and debt are often inconclusive. At longer horizons, distortionary financing is important for the negative investment response to a debt expansion.
\end{abstract}

Keywords: Crowding Out; Distortionary Debt Financing; Fiscal and Monetary Policy Interactions; Bayesian Estimation

JEL Codes: C11; E63; H63

The past decade in the United States has been a period of tremendous fiscal activity: expenditures on the war on terrorism, two major tax cuts in 2001 and 2003, fiscal stimulus packages in 2008 and 2009, and the financial rescue programs. These activities have occurred against a backdrop of demographic trends that suggest accelerated spending increases in future medical programs and Social Security. The Congressional Budget Office (2009) projects that federal debt in 2080 will reach 283 percent and 716 percent, respectively, of GDP under

May 1, 2010. We thank Eric Leeper for his advice and support throughout the project. Also, we thank Robert Dennis, Eric Engen, Juan Carlos Escanciano, Jeffrey Kling, Joon Park, Todd Walker, and all seminar participants at Indiana University, the Congressional Budget Office, the Board of Governors, Princeton University, London Business School, University of Cincinnati, North Carolina State University, Wesleyan University, University of Arkansas, the International Monetary Fund, and Paris School of Economics for helpful comments. Earlier versions were circulated under the title "Does Government Debt Crowd Out Investment? A Bayesian DSGE Approach." The views expressed in this paper are those of the authors and should not be interpreted as those of the Congressional Budget Office. Department of Economics, Indiana University, ntraum@indiana.edu; Congressional Budget Office, sc.susan.yang@gmail.com. 
the extended current-law scenario and an alternative fiscal scenario, suggesting an unsustainable path for U.S. fiscal policy. ${ }^{1}$ The active use of fiscal policy has raised concern about debt accumulation and rekindled a classic economic debate: Will government debt accumulation lead to declines in (i.e. crowd out) private investment?

This paper estimates a dynamic stochastic general equilibrium (DSGE) model using Bayesian methods to evaluate the extent of crowding out by government debt for the U.S. economy. Several recent papers employ Bayesian techniques to understand the economic effects of fiscal policy. Most of them, however, have not modeled in detail the interactions between monetary and fiscal policies or the fiscal adjustments induced by government debt accumulation [Coenen and Straub (2005), Forni, Monteforte, and Sessa (2009), Lopez-Salido and Rabanal (2006), and Leeper, Plante, and Traum (2010)]. In addition, previous DSGE models estimated to study fiscal and monetary interactions have not accounted for several fiscal instruments, such as distortionary taxes [for example, Leeper and Sims (1994) and Kim (2000)]. We incorporate a detailed fiscal specification into a standard New Keynesian model often used for monetary policy analysis. The rich dynamics between monetary and fiscal policy in the model help explain the investment response to government debt accumulation.

Following World War II, many economists were concerned about the impact of government debt [for example, Domar (1944), Leland (1944), Wallich (1946), and the references therein]. Since then, a conventional view has emerged, suggesting that government borrowing is expansionary in the short run but contractionary in the long run. ${ }^{2}$ Keynesian economic theory argues that when prices and wages are sticky, higher debt caused by deficit-financed tax cuts or spending increases adds to aggregate demand, leading income and output to increase. The deficits, however, reduce public saving. If private saving and capital inflows do not increase enough to fully offset government borrowing, interest rates rise over time. Consequently, investment is crowded out, and capital and output eventually decline, negating the short run expansionary benefits.

Building on this theoretical view, many empirical studies have estimated the reduced-form relationship between government debt (or deficits) and interest rates at various horizons. A positive estimated relationship between the two variables is viewed as evidence of crowding out. Surveys of the literature generally conclude a lack of consensus among the findings. ${ }^{3}$ This paper uses an estimated DSGE model to show that even when government debt expansions reduce investment, no systematic reduced-form relationship between debt and real interest rates exists. The result explains why empirical studies focusing on the relationship between interest rates and debt are often inconclusive about the extent of crowding out by government debt.

\footnotetext{
${ }^{1}$ The alternative fiscal scenario incorporates some policy changes that regularly have been made in the past and are widely expected to occur.

${ }^{2}$ See Bernheim (1989) and Elmendorf and Mankiw (1999) for a detailed discussion.

${ }^{3}$ See Barth, Iden, and Russek (1984), Elmendorf and Mankiw (1999), Gale and Orszag (2003), and Engen and Hubbard (2005). Laubach (2009) finds a positive and significant relationship between debt or deficits and interest rates when long-horizon forward rates and projected federal deficits are used. Engen and Hubbard (2005) also obtain similar results using the same measures for the two variables; however, they find that when the dependent variable is the change in the forward rate rather than the level, the positive coefficient is insignificant.
} 
We add fiscal details to a standard New Keynesian model that has been shown to fit data well [Del Negro, Schorfheide, Smets, and Wouters (2007) and Smets and Wouters (2007)]. Most fiscal instruments can respond to government indebtedness, as in Leeper, Plante, and Traum (2010). Income tax rates adjust automatically to the state of the economy, as does the income tax policy in practice. Instead of assuming all government spending is wasteful, we distinguish between government consumption and productive government investment. Since the extent to which consumers are myopic has received much attention in the debate of fiscal policy effects, we include non-savers (also known as liquidity-constrained or rule-of-thumb agents) as well as savers (forward-looking agents with rational expectations), following Gali, Lopez-Salido, and Valles (2007) and Forni, Monteforte, and Sessa (2009). ${ }^{4}$

Aside from the fiscal emphasis, monetary policy is also accounted for. Historical decompositions show that both monetary and fiscal policy shocks are important for debt movements. Further, the path of investment following expansionary fiscal shocks varies qualitatively with various monetary policy parameter combinations. For example, the hawkishness of the monetary authority affects the path of real interest rates, which in turn affect investment decisions. A priori, the model does not impose restrictions on whether government debt crowds out or in investment and on how government debt affects the economy. By estimating most structural and policy parameters in the model, we assess the importance of fiscal and monetary policy as well as other factors for determining the effects of government debt.

Several factors drive the investment response to rising government debt: the source of policy changes that give rise to debt growth, the response of monetary policy, and distortionary debt financing. In the short run, the effect of government debt is mainly determined by the type of fiscal or monetary policy shock that triggers a debt expansion. Higher government debt can crowd in investment despite a higher real interest rate if the debt is generated by a reduction in capital tax rates or by an increase in productive government investment, because both raise the net return to capital. This result is consistent with those from calibrated models [Ludvigson (1996) and Leeper and Yang (2008), and Freedman, Kumhof, Laxton, Muir, and Mursala (2009)]. Over a longer horizon, distortionary financing plays an important role in the negative investment response following a debt expansion. We find that most fiscal instruments respond to debt systematically under rather diffuse priors: when the debt-to-output ratio rises, the government reduces its purchases and transfers and increases income taxes to stabilize debt. Among the various instruments used for fiscal adjustments, raising income taxes, in particular the capital tax rate, has a strong negative impact on investment, as found by Leeper, Plante, and Traum (2010) and Uhlig (2010) in neoclassical growth models.

Monetary policy - particularly the central bank's responsiveness to output - matters systematically for the path of investment. The more aggressively the central bank responds to output fluctuations following a deficit-financed fiscal intervention, the smaller the increase or the larger the decline in investment, depending on which fiscal instrument triggers the debt expansion. In the case of a positive government investment shock, a sufficiently large response in the nominal interest rate can reverse the crowding-in effect on investment in the short run.

${ }^{4}$ The debate concerns whether government debt is perceived as net wealth [Modigliani (1961), Barro (1974), Blanchard (1985), and Smetters (1999)]. If so, people behave myopically as non-savers in our model. 
Finally, we isolate historical fiscal innovations, which allow us to evaluate the effects of individual fiscal policy episodes. We focus on the tax increases in 1990s and the deficitfinanced tax cuts during the recession in 2001 and 2002. Counterfactual exercises find that when the capital and labor tax innovations from 1993Q1 to 1997Q2 are turned off, the real value of federal debt in 1997Q2 is 11 percent higher and investment is 2 percent higher than their historical values, suggesting that the tax adjustments had a negative effect on investment. In addition, although the 2001 and 2002 tax cuts were expansionary, monetary policy played a larger role in counteracting the 2001 recession.

\section{The Estimated Model}

The model is a conventional New Keynesian model based on Christiano, Eichenbaum, and Evans (2005), Smets and Wouters (2007), Gali, Lopez-Salido, and Valles (2007), and Forni, Monteforte, and Sessa (2009). We include two types of households: savers, who are forward-looking with access to complete asset and capital markets, and non-savers, who do not have access to financial or capital markets and consume all of their disposable income each period. Because non-savers have a higher marginal propensity to consume than savers, their presence allows stronger short-run demand effects following expansionary fiscal policy actions than in models with only savers. Non-savers also break Ricardian equivalence, as lump-sum transfers are distortionary.

Other features of the model are standard in the New Keynesian literature. We incorporate two real rigidities - variable capital utilization and investment adjustment costs - and two nominal rigidities for prices and wages, both adjusting by a Calvo (1983) mechanism with partial indexation to past inflation. ${ }^{5}$ The equilibrium system of the model is log-linearized and solved by Sims's (2001) algorithm. ${ }^{6}$. Unless otherwise noted, all exogenous disturbances are assumed to follow $\mathrm{AR}(1)$ processes.

1.1. Households. The economy is populated by a continuum of households on the interval $[0,1]$, of which a fraction $\mu$ are non-savers and a fraction $(1-\mu)$ are savers. The superscript $S$ indicates a variable associated with savers and $N$ with non-savers.

1.1.1. Savers. The household $j \in[0,1-\mu]$ maximizes its utility, given by

$$
E_{0} \sum_{t=0}^{\infty} \beta^{t} u_{t}^{b}\left[\frac{c_{t}^{S}(j)^{1-\gamma}-1}{1-\gamma}-\frac{L_{t}^{S}(j)^{1+\kappa}}{1+\kappa}\right],
$$

where $\beta \in(0,1)$ is the discount factor, $\gamma \geq 0$ is the inverse of the intertemporal elasticity of substitution, and $\kappa \geq 0$ is the labor preference parameter. $u_{t}^{b}$ is a shock to general preferences. The economy has a continuum of differentiated labor inputs indexed by $l \in[0,1]$. We assume that each household supplies all differentiated labor inputs to eliminate labor income discrepancies from individual households supplying differentiated labor services, as in Schmitt-Grohe and Uribe (2004). The total hours supplied by household $j$ satisfies the

\footnotetext{
${ }^{5}$ Habit formation, commonly included in DSGE models, is dropped from the specification. Because non-saver households react to most of the fiscal shocks differently than savers, non-savers serve a function similar to habit for smoothing aggregate consumption.

${ }^{6}$ Technical details of the model's equilibrium system are available in an estimation appendix.
} 
constraint $L_{t}^{S}(j)=\int_{0}^{1} l_{t}^{S}(j, l) d l$, where $l_{t}^{S}(j, l)$ is the amount of labor input $l$ supplied by saver $j$. Hours are demand-driven, and each household $j$ works sufficient hours to meet the market demand for the chosen monopolistic wage rates. The wage decisions are delegated to unions, which are discussed below.

The flow budget constraint in units of consumption goods for saver $j$ is given by

$$
\begin{aligned}
\left(1-\tau_{t}^{L}\right) \int_{0}^{1} \frac{W_{t}(l)}{P_{t}} l_{t}^{S}(j, l) d l+ & \left(1-\tau_{t}^{K}\right) \frac{R_{t}^{K} v_{t}(j) k_{t-1}(j)}{P_{t}}+\frac{R_{t-1} b_{t-1}(j)}{\pi_{t}}+z_{t}(j)+d_{t}(j) \\
& =c_{t}^{S}(j)+\frac{i_{t}(j)}{1+\tau_{t}^{C}}+b_{t}(j)
\end{aligned}
$$

where $\tau_{t}^{L}, \tau_{t}^{K}$, and $\tau_{t}^{C}$ are tax rates on labor income, capital income, and consumption, and $z_{t}(j)$ represents lump-sum government transfers. $W_{t}(l)$ is the nominal wage rate for labor input $l$, and $P_{t}$ is the general consumer price, inclusive of consumption taxes. At time $t$, household $j$ purchases $b_{t}(j)$ units of government debt, which pays $R_{t} b_{t}(j) / \pi_{t+1}$ units of consumption goods at $t+1$, where $\pi_{t+1} \equiv P_{t+1} / P_{t}$ is the gross inflation rate for the consumer price index. $d_{t}(j)$ is dividends received from profits of the monopolistic firms, and $i_{t}(j)$ is saver $j$ 's gross investment. Note that introducing consumption taxes causes a wedge between the producer price index, $\bar{P}_{t}$, and the consumer index, given by $P_{t}=\left(1+\tau_{t}^{c}\right) \bar{P}_{t}$. We assume that no indirect taxes are paid on purchases of investment goods, so that the price index of investment goods is the wholesale price $\bar{P}_{t},{ }^{7}$ as in Forni, Monteforte, and Sessa (2009).

Savers control both the size of the capital stock $k_{t-1}$ and its utilization rate $v_{t}$. A higher utilization rate is associated with a higher depreciation rate of capital:

$$
\delta\left[v_{t}(j)\right]=\delta_{0}+\delta_{1}\left(v_{t}(j)-1\right)+\frac{\delta_{2}}{2}\left(v_{t}(j)-1\right)^{2},
$$

as in Schmitt-Grohe and Uribe (2008). We calibrate $\delta_{1}$ so that $v=1$ in the steady state. We define a parameter $\psi \in[0,1)$ such that $\frac{\delta^{\prime \prime}[1]}{\delta^{\prime}[1]}=\frac{\delta_{2}}{\delta_{1}} \equiv \frac{\psi}{1-\psi}$.

The law of motion for private capital is given by

$$
k_{t}(j)=\left(1-\delta\left[v_{t}(j)\right]\right) k_{t-1}(j)+\left[1-s\left(\frac{u_{t}^{i} i_{t}(j)}{i_{t-1}(j)}\right)\right] \times i_{t}(j),
$$

where $s\left(\frac{u_{t}^{i} i_{t}(j)}{i_{t-1}(j)}\right) \times i_{t}(j)$ is investment the adjustment cost, as in Smets and Wouters (2003) and Christiano, Eichenbaum, and Evans (2005). By assumption, $s(1)=s^{\prime}(1)=0$, and $s^{\prime \prime}(1) \equiv s>0$. In addition, the adjustment cost is subject to an investment-specific efficiency shock $u_{t}^{i}$.

1.1.2. Non-savers. Non-savers have the same preferences as savers, receive the same lumpsum government transfers, and consume all their disposable income each period. The budget constraint in units of consumption goods for the non-saver $j \in(1-\mu, 1]$ is

$$
c_{t}^{N}(j)=\left(1-\tau_{t}^{L}\right) \int_{0}^{1} \frac{W_{t}(l)}{P_{t}} l_{t}^{N}(j, l) d l+z_{t}(j) .
$$

\footnotetext{
${ }^{7}$ Dividing the wholesale price index by the consumer price index leaves the tax wedge, which shows up in the investment cost of $i_{t}(j)$ in units of consumption goods $\frac{i_{t}(j)}{1+\tau_{t}^{c}}$.
} 
1.2. Wage Setting and Labor Aggregation. To introduce wage rigidities, we assume that monopolistic unions set the wages for the differentiated labor services, following Colciago (2007) and Forni, Monteforte, and Sessa (2009). Households supply differentiated labor inputs to a continuum of unions, indexed by $l$. Households are distributed uniformly across the unions, implying that the aggregate demand for a specific labor input is spread uniformly across all households. Therefore, in equilibrium the total hours worked for savers and nonsavers are equal: $L_{t}^{S}(j)=L_{t}^{N}(j)=\int_{0}^{1} l_{t}(l) d l \equiv L_{t}$.

A perfectly competitive labor packer purchases the differentiated labor inputs and assembles them to produce a composite labor service $L_{t}$ (sold to intermediate goods producing firms) by the technology due to Dixit and Stiglitz (1977),

$$
L_{t}=\left[\int_{0}^{1} l_{t}(l)^{\frac{1}{1+\eta_{t}^{w}}} d l\right]^{1+\eta_{t}^{w}}
$$

where $\eta_{t}^{w}$ denotes a time-varying exogenous markup to wages.

The demand function for a competitive labor packer, derived from solving their profit maximization problem subject to (6), is

$$
l_{t}(l)=L_{t}^{d}\left(\frac{W_{t}(l)}{W_{t}}\right)^{-\frac{1+\eta_{t}^{w}}{\eta_{t}^{w}}}
$$

where $L_{t}^{d}$ is the demand for composite labor services, $W_{t}$ is the aggregate wage, and $\frac{1+\eta_{t}^{w}}{\eta_{t}^{w}}$ measures the elasticity of substitution between labor inputs.

In each period, a union receives a signal to reset its nominal wage with probability $\left(1-\omega_{w}\right)$. Those who cannot reoptimize index their wages to past inflation according to the rule

$$
W_{t}(l)=W_{t-1}(l) \pi_{t-1}^{\chi^{w}} \pi^{1-\chi^{w}}
$$

where $\chi^{w} \in[0,1]$ introduces a backward looking component in the inflation process. Unions that receive the signal choose the optimal nominal wage rate $\tilde{W}_{t}(l)$ to maximize the lifetime utility of all households, given by

$$
E_{t} \sum_{i=0}^{\infty}\left(\beta \omega_{w}\right)^{i}\left\{u_{t+i}^{b}\left[(1-\mu) \frac{\left(c_{t+i}^{S}\right)^{1-\gamma}-1}{1-\gamma}+\mu \frac{\left(c_{t+i}^{N}\right)^{1-\gamma}-1}{1-\gamma}-\frac{L_{t+i}^{1+\kappa}}{1+\kappa}\right]\right\}
$$

subject to four constraints: the aggregate budget constraints for savers and non-savers and the individual and aggregate labor demand functions. Since hours worked are equal in equilibrium, we drop the superscripts for savers and non-savers.

In a symmetric equilibrium, where $\tilde{W}_{t}(l)=\tilde{W}_{t}$, the nominal aggregate wage evolves according to

$$
W_{t}=\left[\left(1-\omega_{w}\right) \widetilde{W}_{t}^{\frac{-1}{\eta_{t}^{w}}}+\omega_{w}\left(\pi_{t-1}^{w}\right)^{\frac{-\chi^{w}}{\eta_{t}^{w}}} W_{t-1}^{\frac{-1}{\eta_{t}^{w}}}\right]^{-\eta_{t}^{w}}
$$

where $\pi_{t}^{w} \equiv \frac{W_{t}}{W_{t-1}}$ is the gross wage inflation rate. 
1.3. Firms and Price Setting. The production sector consists of intermediate and final goods producing firms. A perfectly competitive final goods producer uses a continuum of intermediate goods $y_{t}(i)$, where $i \in[0,1]$, to produce the final goods, $Y_{t}$, according to the same constant-return-to-scale technology used by the labor packers,

$$
\left[\int_{0}^{1} y_{t}(i)^{\frac{1}{1+\eta_{t}^{p}}} d i\right]^{1+\eta_{t}^{p}} \geq Y_{t}
$$

where $\eta_{t}^{p}$ denotes an exogenous time-varying markup to the intermediate goods' prices.

We denote the price of the intermediate goods $i$ as $\bar{p}_{t}(i)$ and the price of final goods $Y_{t}$ as $\bar{P}_{t}$. The final goods producing firm chooses $Y_{t}$ and $y_{t}(i)$ to maximize profits subject to the technology (11). The demand for $y_{t}(i)$ is given by

$$
y_{t}(i)=Y_{t}\left(\frac{\bar{p}_{t}(i)}{\bar{P}_{t}}\right)^{-\frac{1+\eta_{t}^{p}}{\eta_{t}^{t}}},
$$

where $\frac{1+\eta_{t}^{p}}{\eta_{t}^{p}}$ is the elasticity of substitution between intermediate goods.

Intermediate goods producers are monopolistic competitors in their product market. Firm $i$ produces by a Cobb-Douglas technology

$$
y_{t}(i)=u_{t}^{a}\left(v_{t} k_{t-1}(i)\right)^{\alpha}\left(l_{t}(i)\right)^{1-\alpha}\left(K_{t-1}^{G}\right)^{\alpha^{G}},
$$

where $\alpha \in[0,1]$, and $\alpha^{G} \geq 0$ is the elasticity of output with respect to government capital $K_{t-1}^{G} \cdot u_{t}^{a}$ denotes a covariance stationary technology shock.

Analogous to labor unions, a monopolistic intermediate firm has a probability of $\left(1-\omega_{p}\right)$ each period to reset its price. Firms that cannot reset optimally index their prices to past inflation according to the rule

$$
\bar{p}_{t}(i)=\bar{p}_{t-1}(i) \bar{\pi}_{t-1}^{\chi^{p}} \bar{\pi}^{1-\chi^{p}} .
$$

Firms that can reset optimally choose their price $\bar{p}_{t}(i)$ to maximize the expected sum of discounted future real profits. In a symmetric equilibrium, where $\bar{p}_{t}(i)=\bar{p}_{t}$, the producer price index $\bar{P}_{t}$ evolves according to

$$
\bar{P}_{t}=\left[\left(1-\omega_{p}\right) \bar{p}_{t}^{\frac{-1}{\eta_{t}^{p}}}+\omega_{p} \bar{\pi}_{t-1}^{\frac{-\chi^{p}}{\eta_{t}^{p}}} \bar{P}_{t-1}^{\frac{-1}{\eta_{t}^{p}}}\right]^{-\eta_{t}^{p}} .
$$

1.4. Monetary Policy. The monetary authority follows a Taylor-type rule, in which the nominal interest rate $R_{t}$ responds to its lagged value, the current inflation rate, and current output. We denote a variable in percentage deviations from the steady state by a caret, as in $\hat{R}_{t}$. Specifically, the interest rate is set according to

$$
\hat{R}_{t}=\rho_{r} \hat{R}_{t-1}+\left(1-\rho_{r}\right)\left[\phi_{\pi} \hat{\pi}_{t}+\phi_{y} \hat{Y}_{t}\right]+\sigma^{m} \epsilon_{t}^{m}, \quad \epsilon_{t}^{m} \sim N(0,1) .
$$


1.5. Fiscal Policy. Each period the government collects tax revenues and issues one-period nominal bonds to finance its interest payments and expenditures, which include government consumption $G_{t}^{C}$, government investment $G_{t}^{I}$, and transfer payments to the households. The flow budget constraint in units of consumption goods is

$$
B_{t}+\tau_{t}^{K} \frac{R_{t}^{K}}{P_{t}} v_{t} K_{t-1}+\tau_{t}^{L} \frac{W_{t}}{P_{t}} L_{t}+\frac{\tau_{t}^{C}}{1+\tau_{t}^{C}} C_{t}=\frac{R_{t-1} B_{t-1}}{\pi_{t}}+G_{t}^{C}+G_{t}^{I}+Z_{t} .
$$

We assume that government investment can be productive. The law of motion for government capital is given by

$$
K_{t}^{G}=\left(1-\delta^{G}\right) K_{t-1}^{G}+G_{t}^{I} .
$$

Fiscal variables respond to the state of the economy according to the following rules:

$$
\begin{gathered}
\hat{\tau}_{t}^{K}=\rho_{K} \hat{\tau}_{t-1}^{K}+\left(1-\rho_{K}\right)\left(\varphi_{K} \widehat{Y}_{t}+\gamma_{K} \hat{s}_{t-1}^{b}\right)+\sigma_{K} \epsilon_{t}^{K}+\phi_{K L} \sigma_{L} \epsilon_{t}^{L}, \\
\hat{\tau}_{t}^{L}=\rho_{L} \hat{\tau}_{t-1}^{L}+\left(1-\rho_{L}\right)\left(\varphi_{L} \widehat{Y}_{t}+\gamma_{L} \hat{s}_{t-1}^{b}\right)+\sigma_{L} \epsilon_{t}^{L}+\phi_{K L} \sigma_{K} \epsilon_{t}^{K} \\
\hat{G}_{t}^{C}=\rho_{G C} \hat{G}_{t-1}^{C}-\left(1-\rho_{G C}\right) \gamma_{G C} \hat{s}_{t-1}^{b}+\sigma_{G C} \epsilon_{t}^{G C}, \\
\hat{G}_{t}^{I}=\rho_{G I} \hat{G}_{t-1}^{I}-\left(1-\rho_{G I}\right) \gamma_{G I} \hat{s}_{t-1}^{b}+\sigma_{G I} \epsilon_{t}^{G I} \\
\hat{Z}_{t}=\rho_{Z} \hat{Z}_{t-1}-\left(1-\rho_{Z}\right) \gamma_{Z} \hat{s}_{t-1}^{b}+\sigma_{Z} \epsilon_{t}^{Z} \\
\hat{\tau}_{t}^{C}=\rho_{C} \hat{\tau}_{t-1}^{C}+\sigma_{C} \epsilon_{t}^{C}
\end{gathered}
$$

where $s_{t-1}^{b} \equiv \frac{B_{t-1}}{Y_{t-1}}$, and $\epsilon_{t}^{s} \sim$ i.i.d. $N(0,1)$ for $s=\{K, L, G C, G I, C, Z\}$.

When the debt-to-output ratio rises above its steady state level, the government can adjust income taxes, government consumption and investment, or transfers to stabilize debt growth. Among the general equilibrium studies with government debt, the vast majority allow for a limited set of fiscal instruments to ensure fiscal solvency. For example, Erceg, Guerrieri, and Gust (2005), Coenen and Straub (2005), and Ratto, Roeger, and in't Veld (2009) allow only lump-sum taxes to respond to debt. Kumhof and Laxton (2007) have several instruments respond to debt but leave out capital taxes. Forni, Monteforte, and Sessa (2009), LopezSalido and Rabanal (2006), Iwata (2009), and Zubairy (2009) allow for income taxes but not government spending to respond to debt. Leeper, Plante, and Traum (2010) find that in the U.S. postwar data, labor and capital taxes, government spending, and transfers all play a role in controlling debt growth. Thus, we allow all fiscal instruments, aside from consumption taxes, to respond to debt. In our data set, consumption taxes consist of federal excise taxes and custom duties, which have an average share of GDP of less than one percent.

To capture the role of income taxes as automatic stabilizers, capital and labor taxes are allowed to respond to output contemporaneously $\left(\varphi_{K}, \varphi_{L} \geq 0\right)$. Because changes in income tax codes often involve changes in labor and capital taxes simultaneously, we also allow an unexpected exogenous movement in one tax rate to affect the other rate, as captured by $\phi_{K L}$ in (19) and (20). We do not allow transfers to include an automatic stabilizer response. Although some transfer components such as food stamps and unemployment insurance are countercyclical, they only take a small share (about 5 percent on average) of the federal transfers data in our sample. 
1.6. Aggregation. We denote the aggregate quantity of a variable $x_{t}$ by its capital letter $X_{t}$. Aggregate consumption is given by

$$
C_{t}=\int_{0}^{1} c_{t}(j) d j=(1-\mu) c_{t}^{S}+\mu c_{t}^{N} .
$$

Lump-sum transfers are assumed to be identical across households, implying that

$$
Z_{t}=\int_{0}^{1} z_{t}(j) d j=z_{t}
$$

Because only savers have access to the asset and capital markets, aggregate bonds, private capital, investment, and dividends are

$$
\begin{aligned}
B_{t} & =\int_{0}^{1} b_{t}(j) d j=(1-\mu) b_{t}, \quad K_{t}=\int_{0}^{1} k_{t}(j) d j=(1-\mu) k_{t}, \\
I_{t} & =\int_{0}^{1} i_{t}(j) d j=(1-\mu) i_{t}, \quad D_{t}=\int_{0}^{1} d_{t}(j) d j=(1-\mu) d_{t} .
\end{aligned}
$$

Finally, the goods market clearing condition is

$$
Y_{t}=C_{t}+I_{t}+G_{t}^{C}+G_{t}^{I}
$$

\section{Estimation}

We estimate the model with U.S. quarterly data from 1983Q1 to 2008Q1. The choice of the sample period is driven by two stability considerations: (1) monetary policy is thought to be characterized by a Taylor rule [Taylor (1993)] over this period; and (2) on average, monetary policy is thought to have been active and fiscal policy passive (in the sense of Leeper (1991)). ${ }^{8}$

We use Bayesian inference methods to construct the parameters' posterior distribution, which is a combination of the likelihood function and prior information (see An and Schorfheide (2007) for a survey). ${ }^{9}$ The likelihood function is estimated using 12 observables, including real aggregate consumption, investment, labor, wages, the nominal interest rate, the gross inflation rate, and fiscal variables - capital, labor, and consumption tax revenues, real government consumption and investment, and transfers. ${ }^{10}$ Although the literature typically uses fiscal variables of all governments, our fiscal variables are for the federal government only. Because state and local governments generally have balanced-budget rules of various forms, fiscal financing decisions are likely to differ across federal and state and local governments,

\footnotetext{
${ }^{8}$ When a longer sample is used, regime-switching between active and passive monetary and fiscal policies is a more pronounced issue. Davig and Leeper (2006) find evidence for regime-switching in the postwar U.S. data. Because the monetary and fiscal policy rules we estimate are assumed to have constant coefficients for inflation and debt, we select a sample period where, on average, monetary policy is active and fiscal policy is passive.

${ }^{9}$ The estimation appendix includes details of the estimation, diagnostics, and additional results.

${ }^{10}$ By not including debt, the invertibility test in Fernandez-Villaverde, Rubio-Ramirez, Sargent, and Watson (2007) fails. However, posterior mode estimation based on simulated data shows that our observables can recover true parameters well. If we include debt as an observable, then one fiscal variable must be dropped to avoid singularity. This makes us unable to accurately estimate the standard deviation of the dropped fiscal variable, which further prevents us from conducting historical decompositions later.
} 
and we only consider modeling the former. Appendix A provides a detailed description of the data. We detrend the logarithm of each time series with its own linear trend, except for the nominal interest rate, which is detrended by the trend in inflation. ${ }^{11}$

2.1. Prior Distributions. We impose dogmatic priors over several parameters that are hard to identify from the data. The discount factor, $\beta$, is set to 0.99 , which implies an annual steady-state real interest rate of 4 percent. The capital income share of total output, $\alpha$, is set to 0.36 , implying a labor income share of 0.64 . The quarterly depreciation rate for private capital, $\delta_{0}$, is set to 0.025 so that the annual depreciation rate is 10 percent. We set $\delta^{G}=0.02$, comparable to the calibrated value in DSGE models with productive investment [Baxter and King (1993) and Kamps (2004)]. We assume that the steady state elasticity of substitution in the goods and labor market $\left(\left(1+\eta^{p}\right) / \eta^{p},\left(1+\eta^{w}\right) / \eta^{w}\right)$ is 8 , implying the steady-state markups in the product and labor markets are approximately 14 percent. This is consistent with evidence that the average price markup of U.S. firms is around 10-15 percent [Basu and Fernald (1995)]. Since there appears to be no consensus in the literature for the average markup in the U.S. labor market, we pick the same value for $\eta^{w}$ by symmetry. The steady-state inflation rate, $\pi$, is assumed to be 1 .

The elasticity of output to government capital, $\alpha^{G}$, cannot be identified without information about the capital stocks. The empirical literature has a wide range of values for $\alpha^{G}$, ranging from a small negative number [Evans and Karras (1994)], to zero [Kamps (2004)], to near 0.4 [Pereira and de Frutos (1999)]. For the baseline estimation, we make a conservative assumption on the productiveness of public capital and calibrate $\alpha^{G}=0.05$. Sensitivity analysis explores two alternative cases where $\alpha^{G}=0$ and $\alpha^{G}=0.1$. We find that the data cannot distinguish between the three values for $\alpha^{G}$ (see Table 3), as the log marginal data densities in the three cases are virtually identical.

The rest of the calibrated parameters are steady-state fiscal variables computed from the means of our data sample: The federal government consumption to output share is 0.070 , the federal government investment to output share is 0.004 , the federal debt to annualized output share is 0.386 , the average marginal federal labor tax rate is 0.209 , the capital tax rate is 0.196 , and finally, the consumption tax rate is 0.015 . When computing these shares, we use an output measure that is consistent with our model specification-namely, the sum of consumption, investment, and total government purchases.

Columns 2 to 5 in Table 1 list the prior distributions for all estimated parameters. Our priors are similar to those in Smets and Wouters (2007) for the parameters found in both models. The domains cover a range of values estimated by previous studies (see Smets and Wouters (2003) and (2007) for a review of previous estimates).

A parameter less encountered in the literature is the share of non-savers, $\mu$. Forni, Monteforte, and Sessa (2009) and Iwata (2009) center the prior at 0.5 but obtain an estimate

\footnotetext{
${ }^{11}$ There is no consensus in the literature on a detrending method (see Canova (2009) for a discussion of the advantages and disadvantages of various detrending methods). An alternative approach is to allow some shocks to be non-stationary and match the demeaned data to its model counterparts. Since several fiscal variables appear to have their own trends in the data, allowing some shocks to be non-stationary is nontrivial. In addition, it is unclear which non-fiscal shocks should be modeled as non-stationary, as various ones have been proposed to better match the data (see Greenwood, Hercowitz, and Krusell (1997), Greenwood, Hercowitz, and Krusell (2000), and Chang, Doh, and Schorfheide (2007)).
} 
around 0.35. Lopez-Salido and Rabanal's (2006) estimate using U.S. data over a similar sample period is between 0.10 to 0.39. Based on this information, we choose a beta prior with a mean of 0.3 and standard deviation equal to 0.1 .

The priors for the fiscal parameters are chosen to be fairly diffuse and cover a reasonably large range of the parameter space. To stabilize debt as a share of output, government spending and transfers should respond negatively to a debt increase, and taxes should respond positively. We assume normal distributions for the fiscal instruments' responses to debt $\left(\gamma_{G C}, \gamma_{G I}, \gamma_{K}, \gamma_{L}\right.$, and $\left.\gamma_{Z}\right)$ with a mean of 0.15 and standard deviation of 0.1 . While these priors place a larger probability mass in the regions of expected signs, a small probability is allowed for the opposite signs. Our guidance to determine the prior range for the $\gamma$ 's is based on two considerations. First, when the $\gamma$ 's are too high, overshooting occurs, resulting in oscillation patterns that are not observed in the data. Second, when the $\gamma$ 's are too low, under active monetary policy, there does not exist an equilibrium.

As capital and labor taxes are progressive in the tax code, we restrict $\varphi_{K}$ and $\varphi_{L}$ to be positive, following a gamma distribution. Since we incorporate Social Security taxes in our labor tax revenues, the labor tax rate elasticity is expected to be a value below the capital tax rate elasticity (since Social Security contributions have a cap and are regressive). The parameter measuring the co-movement between capital and labor tax rates $\left(\sigma_{K L}\right)$ is assumed to have a normal distribution with a mean of 0.2 and a standard deviation of 0.1 . The domain covers the range of past estimates for this parameter [see Leeper, Plante, and Traum (2010) and Yang (2005)].

A priori, our model does not impose restrictions on whether government debt crowds out or in investment. Table 2 quantifies the extent of crowding out based on 30,000 draws from the prior and posterior distributions. The top rows record the percentage of draws that lead investment to decline on impact of various fiscal shocks. Except for government consumption and transfer increases, the priors can deliver positive or negative investment responses on impact following expansionary fiscal policy shocks. The bottom rows report the 5 th and 95 th cumulative present-value investment multipliers following various fiscal shocks. ${ }^{12}$ With the exception of a government investment increase or consumption tax decrease, the priors allow the 90 percent interval of the investment multipliers to cover both signs, indicating that the path of investment can vary qualitatively for various parameter combinations. Even though the present-value investment multipliers for government investment always are positive and for consumption taxes always are negative, on impact the priors do not restrict the sign of the investment response. Thus, in these cases (as well as the others) the model allows for the longer-term dynamics to vary qualitatively from the short-run dynamics. Section 3 explores the economics of both short-run and longer-run responses to expansionary fiscal shocks.

2.2. Posterior Estimates. The last two columns of table 1 provide the mean, and 90th percentiles from the posterior distributions. Because the prior and posterior 90th percentiles for the labor preference parameter, $\kappa$, and the responses of tax rates to contemporaneous

\footnotetext{
12 Investment multipliers are defined as the present-value sum of investment changes in levels divided by the present-value sum of changes in a fiscal variable. Depending on the fiscal shock that triggers debt growth, the denominator can be changes in capital, labor, or consumption tax revenues, government consumption or investment, or transfers. The sums are over 1000 quarters, and present values are discounted by the model-implied interest rate path.
} 
output, $\varphi_{K}$ and $\varphi_{L}$, are very similar, it appears these parameters are not well identified from the data.

Overall, the estimates for the common parameters in New Keynesian models are comparable to others estimated with postwar U.S. data [Smets and Wouters (2007), Del Negro, Schorfheide, Smets, and Wouters (2007), and Fernandez-Villaverde, Guerron-Quintana, and Rubio-Ramirez (2010)]. Our estimate of the risk aversion parameter is larger than the values estimated or calibrated in previous studies, implying an intertemporal elasticity of substitution of $0.37 .{ }^{13}$ The rest of this section discusses parameters less frequently encountered in the literature and how well the model fits the data.

2.2.1. Fraction of non-savers. The mean estimate for the fraction of non-savers $\mu$ is 0.18 , and the 5th and 95th percentiles are $[0.10,0.27]$. The relatively low fraction of non-savers suggests the importance of forward-looking behavior in explaining the aggregate effects of fiscal policy. Although myopic behavior has been important in explaining fiscal policy effects in the literature since Mankiw (2000) and Gali, Lopez-Salido, and Valles (2007), our mean estimate is much smaller than the commonly calibrated value of 0.5 , based on single-equation estimation of a consumption function [Campbell and Mankiw (1989) and Gali, Lopez-Salido, and Valles (2007)]. Previous studies have incorporated non-savers into models so that aggregate consumption can increase following a positive government spending shock. Given the mean estimates for the benchmark model, our model requires a fraction of 0.45 in order to deliver a positive short-term consumption response to an increase in government consumption, which falls outside the 90-percent interval. Our results are consistent with vector autoregression (VAR) estimates. VARs with either federal government consumption alone or the sum of federal government consumption and investment find that, for our sample period (1983Q1 to 2008Q1), an increase in government spending does not have a positive effect on consumption. ${ }^{14}$

2.2.2. Fiscal rules. Most fiscal instruments have the expected signs for their responses to government debt as a share of output, despite the fact that the priors allow for the opposite signs. We find that the federal government relies on raising income taxes and reducing government consumption to stabilize debt, as in Leeper, Plante, and Traum (2010). The mean estimate for government investment's response is negative, but the 90-percent interval encompasses zero (as does the 90-percent interval for the response of transfers to debt), indicating that government investments (and transfers) were not used systematically for controlling debt growth.

\footnotetext{
${ }^{13}$ The literature has a wide range of estimates for this parameter [Guvenen (2006)].

${ }^{14}$ The VARs are ordered with government spending first, followed by GDP, consumption, and investment. Identification is achieved using a Cholesky decomposition. The evidence of the positive consumption response following a government spending shock found in the literature [e.g. Gali, Lopez-Salido, and Valles (2007) and Bouakez and Rebei (2007)] is based on a longer postwar U.S. sample. VARs based on shorter, more recent samples [Perotti (2005) and Bilbiie, Meier, and Mueller (forthcoming)] find a muted consumption response.
} 
2.3. Debt Dynamics. Historical decompositions in Figure 1 show the model-implied dynamics of real debt and the real primary deficit (defined as the sum of government consumption, investment, and transfers less total tax revenues). ${ }^{15}$ The top row presents the breakdown of all shocks organized by monetary, fiscal (aggregating tax, government spending, and transfers), and structural (aggregating all non-policy) shocks; the bottom two panels further decompose among the six fiscal shocks. The thick solid lines are the model-implied data series, and the units on the y-axis are percentage deviations from the steady-state path. The bottom two panels plot the decomposition for the six fiscal shocks. They suggest that the dominant driving forces (in the order from the darkest to lightest shade) are shocks to government consumption, capital taxes, labor taxes, and transfers.

Overall, fiscal shocks are the most important sources for movements in real debt. The series implies that the fiscal position gradually worsened throughout the 1980s. The increases in federal government consumption and investment (rising from about 8 percent of GDP in 1979 to 10 percent in 1986) and the reductions in individual and corporate income tax rates (enacted in the Economic Recovery Tax Act of 1981 and the Tax Reform Act of 1986) are the main factors contributing to this surge. Debt steadily declined from 1996 until 2000. The improvement was mainly due to an increase in individual income tax rates on the relatively high income brackets (enacted in the Omnibus Budget Reconciliation Act of 1993) and a decrease in federal spending (falling from 9 percent in 1990 to about 6 percent in the late 1990s). The model-implied deficit series experiences a small spike in 1991, moving from above the trend to below the trend in the first quarter of 1991 before continuing to further increase above the trend until approximately 1993. This corresponds with the Omnibus Budget Reconciliation Act of 1990's enactment to increase the highest income tax rates, which became effective January 1, 1991.

In addition to fiscal shocks, monetary policy shocks also play an important role in real debt movements. Starting in 1994, monetary policy shocks offset fiscal innovations to reduce debt. Positive interest rate disturbances drove up the real value of debt by increasing interest rate payments. This corresponds with the Federal Reserve's actions. Starting in 1994, the Fed raised the federal funds rate in anticipation of increasing future inflation rates, as noted by Kohn (1995). Analogously, when the federal funds rate was gradually lowered, starting on January 3, 2001, in response to the economic downturn, monetary policy contributed to lowering the real value of debt.

\section{Crowding Out By Government Debt}

Fiscal and monetary shocks are the main driving forces for the real value of U.S. government debt in the post-1983 sample. This section investigates the economics underlying the links between investment and government debt, focusing on the debt changes driven by fiscal and monetary policy shocks.

\footnotetext{
${ }^{15}$ We use the posterior mean estimates and the Kalman smoother to obtain values of the innovations for each shock. The discrepancies between the model-implied values and the shock contributions are due to initial conditions. See Alvarez-Lois, Harrison, Piscitelli, and Scott (2008) for more details on the construction of the decomposition.
} 
We first examine the model implied Tobin's q [Tobin (1969)]. Define $q_{t} \equiv \frac{\xi_{t}\left(1+\tau_{t}^{C}\right)}{\lambda_{t}^{S}}$, where $\lambda_{t}^{S}$ and $\xi_{t}$ are the Lagrangian multipliers for the constraints (2) and (4) in the savers' utility optimization problem. $q_{t}$ has the interpretation of the shadow price of increasing capital at the end of $t$ by one unit. Investment tends to rise with $q_{t}$. The log-linearized expression of Tobin's q from its steady state is

$$
\begin{gathered}
\hat{q}_{t}=\frac{\tau^{C}}{1+\tau^{C}} \hat{\tau}_{t}^{C}-\left(\hat{R}_{t}-E_{t} \hat{\pi}_{t+1}\right)+\beta\left(1+\tau^{C}\right)\left(1-\tau^{K}\right) r^{K} E_{t} \hat{r}_{t+1}^{K} \\
-\left[\tau^{K} r^{K} \beta\left(1+\tau^{C}\right)\right] E_{t} \hat{\tau}_{t+1}^{K}+\beta(1-\delta) E_{t} \hat{q}_{t+1}-\frac{\beta \tau^{C}(1-\delta)}{\left(1+\tau^{C}\right)} E_{t} \hat{\tau}_{t+1}^{C},
\end{gathered}
$$

where $r_{t}^{K} \equiv \frac{R_{t}^{K}}{P_{t}}$ is the real rate of return for private capital.

Consistent with the conventional view, the negative coefficient on the real interest rate $\left(\hat{R}_{t}-E_{t} \hat{\pi}_{t+1}\right)$ indicates that a higher real rate discourages investment. Equation (26) also points out that investment decisions are influenced by several other factors. A higher expected real return on capital makes agents want to invest more, but a higher expected capital tax rate does the opposite. In the model, the consumption tax shock serves as a relative price shock between consumption and investment, because consumption taxes are levied only on consumption goods. An increase in the consumption tax signals a fall in the price of investment goods relative to consumption goods. In contrast, expectations of future cheaper investment goods, through an expected increase in the future consumption tax rate, delay investment decisions. The higher expected shadow price indicates that capital is more valuable in the future, so it encourages current investment. Finally, by iterating on this equation, we see that investment depends not only on the current values of these variables, but on their entire expected future paths. Next, we examine how fiscal and monetary shocks affect investment decisions.

3.1. Fiscal Policy and Crowding Out. When a fiscal shock hits the economy, it has a direct effect on the evolution of variables from the shock itself and a secondary effect through future debt financing. Delayed financing causes government debt to accumulate, which brings forth future policy adjustments that can affect both the current economy (through policy expectations) and the future economy (through the implementation of policy adjustments). We first look at the relationship between debt and investment implied by the overall effect of a fiscal policy shock. Later we contrast the results with the net effect from debt financing.

Figures 2 and 3 show one standard deviation impulse responses to all policy shocks. The solid lines are the responses under the posterior mean estimates. The dotted-dashed lines give the 5th and 95th percentiles based on the posterior distributions. The y-axis measures percentage deviation from the steady state, and the $\mathrm{x}$-axis denotes the number of years after a shock.

Although all the expansionary fiscal shocks cause government debt to grow, investment can rise or fall, depending on the type of shock. When government investment increases or the capital tax rate decreases, higher debt is associated with higher private investment, as shown by the solid lines in the second and third columns of Figure 2. An increase in productive government investment implies a higher stock of future public capital, which raises the marginal product of private capital $\left(E_{t} \hat{R}_{t+1}^{K}\right.$ in equation (26)). A reduction in 
the capital tax rate directly increases the after-tax rate of return for investment. Because the tax shock is persistent, this lowers expectations of future capital tax rates. In the conventional view crowding out results from decreases in national saving, which drives up the real interest rate and lowers investment. We see that if a debt expansion is due to an increase in government investment or a decrease in the capital tax rate, the higher expected return to capital or the lower expected capital tax rate causes investment to rise despite a higher interest rate, as suggested by equation (26).

When labor or consumption tax rates decrease (the first and second columns of Figure 3), the probability intervals allow for investment to be crowded in or out in the short run. A negative labor tax shock increases labor demand, which drives up the marginal product of capital, and hence makes agents want to invest more. However, the deficit-financed labor tax cut induces policy adjustments, which involve higher capital and labor tax rates and lower government spending. For most combinations of parameters drawn from the posterior distributions, these fiscal adjustments discourage investment (income tax adjustments deter investment, as can be seen from equation (26)). For the reduction in the consumption tax rate, the direct effect is a reduction in investment as investment goods become more expensive than consumption goods. The initial positive response of investment is driven by the monetary authority's interest rate response: the more aggressively the monetary authority stabilizes prices (following the decrease in the consumer's price level), the more the real interest rate declines, which drives up investment. Investment is crowded out despite a lower interest rate in the medium-run.

Among the six fiscal shocks, the only two shocks that produce debt effects largely consistent with the conventional view are government consumption and transfers shocks. The first column of Figure 2 shows that following an increase in government consumption, the real interest rate rises and investment falls. When the government absorbs a larger share of goods, it leaves the private sector with fewer goods to invest. As goods become more valuable, the real interest rate rises to clear the goods market. A similar pattern is also observed with the transfer shock (the third column of Figure 3). Rising transfers increase aggregate consumption because non-savers consume more due to higher disposable income. Higher demand for goods drives up the real interest rate, discouraging investment.

The above discussion shows that a debt expansion need not lead the real interest rate to rise and investment to fall. The relationships among these variables depend on which fiscal innovation triggers the debt growth.

3.1.1. Distortionary debt financing. One important channel in which government debt can affect the economy is through policy adjustments necessary to stabilize debt. To understand the effects of distortionary debt financing, we construct a hypothetical economy that is identical to the benchmark economy except for the manner in which government debt is financed. In the hypothetical economy, the government follows a balanced budget rule, and $\gamma_{G C}=\gamma_{G I}=\gamma_{K}=\gamma_{L}=\gamma_{Z}=0$. We introduce a new lump-sum tax $X_{t}$ on savers, which shows up only in the savers' budget constraints, and evolves to satisfy

$$
X_{t}=G_{t}^{C}+G_{t}^{I}+Z_{t}-\tau_{t}^{K} \frac{R_{t}^{K}}{P_{t}} v_{t} K_{t-1}-\tau_{t}^{L} \frac{W_{t}}{P_{t}} L_{t}-\frac{\tau_{t}^{C}}{1+\tau_{t}^{C}} C_{t}
$$


Because savers possess rational expectations and have access to asset markets, the lump-sum tax is non-distorting and does not affect savers' marginal decisions. In this economy, the dynamics of aggregate variables are not affected by the lump-sum tax $X_{t}$, and no government debt accumulates. This is the only way in which the hypothetical economy differs from the estimated model.

Returning to Figures 2 and 3, we now examine the dashed line responses - the differences between the responses of the benchmark and hypothetical economies computed using the posterior mean parameter values, or the responses due solely to distortionary financing of debt. The investment responses are mostly negative, with the exception of the government investment shock. This indicates that the negative effect on investment is more pronounced under distortionary fiscal financing. At the same time, the differences between the responses of the real interest rate in the two economies are negligible, demonstrating that the differences in the investment movements are not due to interest rate effects.

It is worth noting that among the five fiscal instruments allowed to respond to debt growth, not every instrument has a negative effect on investment. Raising capital or labor tax rates and reducing government investment has negative impacts on investment, but cutting government consumption or transfers does not. Thus, the effect of debt financing depends crucially on the policy combination to retire debt. Our estimates suggest capital and labor taxes have undertaken most fiscal adjustments in the post-83 period, which explains why distortionary fiscal financing have a negative effect on investment.

3.2. Monetary Policy and Crowding Out. The historical decompositions in Section 2.3 show that monetary policy shocks are important for real debt movements. In addition, the literature has noted that monetary policy can influence the degree of crowding out [for example, Buiter and Tobin (1980) and Brunner and Meltzer (1972)].

The last column of Figure 3 reports the impulse responses to a debt surge driven by an exogenous tightening in monetary policy (an increase in the nominal interest rate). A higher nominal interest rate leads the price level to fall and hence the real interest rate to rise. This induces savers to substitute away from capital and into government bonds. The real value of government debt rises because the higher nominal rate increases interest payments to service debt. Because the debt growth is accompanied by a rising real rate and declining investment, it is consistent with the conventional view on crowding out. This implies that reduced-form regressions that do not control for monetary policy could find a positive relationship between debt and real interest rates and conclude crowding out occurs, even if the effect is due to monetary - not fiscal-policy.

To further investigate how monetary policy can influence the degree of crowding out, we compare the responses to various fiscal shocks under different response magnitudes of the nominal interest rate to inflation and output: $\phi_{\pi}=1.05,1.7$, and 2.5; $\phi_{Y}=0,0.11$, and 0.3. All other parameters are kept at their posterior mean estimates. Figure 4 depicts the responses following exogenous changes of one standard deviation in each fiscal instrument (as in Figures 2 and 3) under three $\phi_{\pi}$ values. The y-axis is in percentage deviation from the steady state. The x-axis denotes the number of years after the shock. 
3.2.1. Response magnitudes to inflation. Varying how aggressively the monetary authority reacts to inflation can have qualitative and quantitative effects on the responses of variables following expansionary fiscal shocks. The monetary authority's hawkishness influences inflation expectations and the real rate, which can change the short-run response of investment under some values of $\phi_{\pi}$.

Following an increase in government consumption or transfers, the price level rises due to increased demand. The weaker the monetary authority's reaction to inflation (i.e. the lower the value of $\phi_{\pi}$ ), the more likely the real interest rate is to decrease, and the smaller the crowding out by government debt, as shown by the first and last columns of Figure 4. Crowding out for an increase in government consumption or transfers is smallest when $\phi_{\pi}=1.05$. Following the labor tax cut, the price level falls initially because of increased production but soon turns positive from higher consumption. When the monetary authority is more dovish, the real interest rate can turn negative, and government debt can crowd in investment under $\phi_{\pi}=1.05$ for the first year, compared with the crowding out result under $\phi_{\pi}=1.7,2.5$.

In contrast, the positive investment response is the smallest (or can turn negative) under government investment or capital tax shocks when $\phi_{\pi}=1.05$. Both shocks initially reduce the price level due to increased levels of production. When the monetary authority is more dovish, the real interest rate rises more, discouraging investment. In the case of a government investment increase, under $\phi_{\pi}=1.05$, government debt crowds out investment for the first two years, before it turns positive. As the price level falls more under the smaller value of $\phi_{\pi}$, the real marginal cost of production is also higher, leading profits to fall. Declining profits reduce the demand for capital, and hence, investment can be below its steady-state level in the short run (as shown by the dashed lines).

For the consumption tax shock, investment can also be crowded in or out in the short run depending on the value of $\phi_{\pi}$. As mentioned earlier, a lower consumption tax rate makes investment goods relatively more expensive than consumption goods, leading investment to decline. However, higher values for $\phi_{\pi}$ lead to larger declines in the real interest rate following a consumption tax shock, driving up invest. As shown by the dashed-dotted lines in the second to the last column in Figure 4, when $\phi_{\pi}=2.5$, government debt can crowd in investment in the short run under a reduction in the consumption tax rate.

3.2.2. Response magnitudes to output. Although we do not observe a systematic relationship between the monetary authority's response to inflation and investment, a systematic relationship exists between the monetary authority's response to output and investment. A larger value of $\phi_{Y}$ is associated with a smaller investment response - either a less positive or more negative response. Higher $\phi_{Y}$ values imply that the central bank raises the nominal interest rate more in response to an output expansion due to a deficit-financed fiscal intervention. A higher nominal interest rate implies a higher real rate (either a more positive or less negative change), which induces agents to demand more government bonds and less capital; hence, investment rises less (or falls more). For the case of a government investment increase or consumption tax decrease, private investment can, in the short run, be crowded in or out depending on the values of $\phi_{Y}$. 


\section{Reduced-Form Estimates}

The results of the previous section suggest that a causal relationship between government debt, investment, and real interest rates is difficult to infer without controlling for which policy innovation triggers a debt expansion. Thus, the prevailing empirical approach to search for evidence of crowding out by focusing on the reduced-form relationship between government debt or deficits and real interest rates is inappropriate and subject to serious identification problems.

To demonstrate this, we simulate 500 data series using the mean estimates of the posterior distribution, ${ }^{16}$ and estimate the reduced-form OLS equations

$$
\begin{aligned}
\hat{r}_{t} & =\beta_{0}+\beta_{1} \hat{s}_{t}^{b}+\epsilon_{t} \\
\hat{r}_{t}^{10} & =\beta_{0}+\beta_{1} \hat{s}_{t}^{b}+\epsilon_{t}
\end{aligned}
$$

for each data series. $\hat{s}_{t}^{b}$ is the model-implied debt-to-GDP ratio, and $\hat{r}_{t}$ is the model-implied one period real interest rate. Because the literature often focuses on the relationship between debt and interest rates with a longer horizon, we also construct $\hat{r}_{t}^{10}$, the model-implied tenyear real rate, which is generated by imposing the pure expectations hypothesis of the term structure.

Table 4 displays the estimates for the mean and 90-percent interval of $\beta_{1}$ from the regressions. The reduced-form estimates from the model can be positive, negative, or zero. The relationship depends strongly on the relative magnitudes of the simulated disturbances. When only government consumption shocks or monetary policy shocks are simulated (and all other disturbances are set to zero), there is a small, positive relationship between the tenyear real interest rate and the debt-to-GDP ratio, consistent with the impulse responses in Figure 2. In contrast, when only labor tax shocks are simulated, the reduced-form relationship is estimated as negative or zero. This result offers an explanation as to why empirical studies that focus on the reduced-form relationship between interest rates and debt are often inconclusive. Because the real interest rate movements depend on the source of the shocks that result in debt growth, and because different shocks can have different implications for interest rates, the estimated sign depends on the relative magnitudes of innovations and, thus, the sample period estimated.

Aside from producing a wide range of reduced-form estimates on the coefficient of debt to interest rates, the model, using the estimated sequence of historical innovations (calculated using the Kalman smoother), can reproduce magnitudes of $\beta_{1}$ comparable to the literature. Table 5 gives the reduced-form estimates using the mean parameters of the posterior distribution, as well as the 90-percent intervals of reduced-form estimates from the entire posterior distribution of the parameters. A one percentage increase in the debt-to-GDP ratio from its steady-state value is estimated, using the mean parameters, to increase the ten-year real interest rate by 2.7 basis points. Previous studies [Laubach (2009), Engen and Hubbard (2005), and Gale and Orszag (2004)] find that a one-percentage point increase in the government debt to GDP ratio leads to an increase of approximately three to six basis points in the real interest rate. For instance, Engen and Hubbard (2005) estimate a 4.7

\footnotetext{
${ }^{16}$ For each case, we simulate a series 1000 periods long and burn the first 900 periods, leaving a sample size comparable to our data series.
} 
basis point increase, which falls within the range of estimates from the posterior distribution (the values in parenthesis in Table 5). Furthermore, 61 percent of the regression estimates were insignificant at the 10 percent level, consistent with the findings of Engen and Hubbard (2005).

Given the complicated interactions among debt, interest rates, and investment, it is not surprising that the reduced-form approach cannot identify crowding out by government debt. This suggests that one should be cautious in interpreting reduced-form relationships between the real interest rate and debt as evidence of crowding out.

\section{Counterfactual Applications}

DSGE estimation provides an analytical framework to assess the effects of historical policy interventions. Having estimated fiscal innovations from the data, we pursue two counterfactual exercises to examine the effects of two fiscal interventions; the first was intended to rein in debt growth (the tax increases and spending cuts in the 1990s), and the second aimed to stimulate the economy (the tax cuts in the early 2000s).

5.1. The Impact of Tax Increases in the 1990s. We ask how the economy would have evolved if there had been no fiscal policy innovations from 1993Q1 to 1997Q2, a period of contractionary fiscal policy (roughly between the enactment of the Omnibus Budget Reconciliation Act of 1993 and the Taxpayer Relief Act of 1997). Figure 5 plots five paths of key macroeconomic variables in the model: solid lines are conditional on the estimated sequence of all shocks; dashed lines are conditional on the estimated sequence of all shocks except capital and labor tax disturbances; dotted lines are conditional on the estimated sequence of all shocks except expenditure shocks (government consumption, government investment, and transfer shocks); dotted-dashed lines are conditional on the estimated sequence of all shocks except fiscal policy shocks; and dots are conditional on the estimated sequence of all shocks except the monetary policy shock.

The real value of federal government debt would have continued to grow if exogenous tax changes (tax movements in addition to those implied by the endogenous feedback in the tax rules) had not occurred. The capital and labor tax increases enacted over the period led debt to be 11 percent lower than it otherwise would have been by the second quarter of 1997. To a lesser extent, innovations to government consumption and investment, consumption taxes, and transfers also contributed to debt retirement; debt would have been 6 percent higher without changes to these fiscal instruments. The contractionary tax actions had a negative effect on private investment: investment would have been about 7 percent higher without the tax increases. This provides evidence that fiscal adjustments, which are necessary to maintain budget sustainability, can have nontrivial negative effects on the economy. If the government had delayed actions to control the debt growth, the consequences to retire debt would have been more severe because the magnitude of the tax increases necessary to offset the debt growth would have been larger.

In contrast, when all fiscal policy shocks during this period are turned off, investment would have been 0.5 percent lower than its observed path in the second quarter of 1997. Note that when government expenditures alone are reduced for fiscal adjustments, they have 
a positive effect on investment (but a negative effect on output). This effect offsets the negative investment response from higher tax rates. Thus, the effects of debt retirement for individual historical episodes depend on the specific combination of fiscal adjustments.

Figure 5 also shows the effects of monetary policy disturbances over the period. During this episode, the monetary authority raised the nominal interest rate to combat inflationary pressures. Without these positive monetary policy shocks, output and inflation would have been higher and government debt lower (because interest payments would have been lower without the increased interest rates). Over this period, the fiscal authority acted to reduce the deficit, while the monetary authority's actions worked to sustain it. In addition, the monetary authority acted to reduce inflation while the fiscal authority's actions, particularly the tax increases, contributed to inflationary pressures.

5.2. The Impact of Tax Cuts in 2001 and 2002. Next, we ask how the economy would have evolved if capital and labor tax or monetary policy innovations were turned off from 2001Q3 to 2002Q4 (after the enactment of the Economic Growth and Tax Relief Reconciliation Act of 2001). Because monetary and fiscal policies were both adopted to counteract the recession in 2001, we examine the relative effectiveness of countercyclical fiscal and monetary policies for this particular recession. Figure 6 contains three paths of key macroeconomic variables in the model: Solid lines are conditional on the estimated sequence of all shocks; dashed lines are conditional on the estimated sequence of all shocks except capital and labor tax disturbances; dotted-dashed lines are conditional on the estimated sequence of all shocks except the monetary policy shock.

The real value of federal government debt would have continued its trend of decline from the late 1990s if discretionary tax changes had not occurred. The tax cuts made the real value of federal debt 7 percent higher than it otherwise would have been by the end of 2002 . On the other hand, the lower interest rates due to discretionary monetary policy helped reduce interest payments to service debt and hence the total amount of debt. The lower nominal interest rate reduced the real value of debt by 3 percent by 2002Q4.

The tax cuts in 2001 and 2002 had mild expansionary effects: In 2002Q4, consumption, output, and investment would have been $0.5,0.8$, and 2.2 percent higher than if the tax cuts were not enacted. Monetary policy, however, appeared to be more effective in counteracting the recession. In particular, consumption and output were 0.95 and 1.2 percent higher than they would have been without the monetary policy interventions. Also, the effects of monetary and fiscal actions on inflation worked in the opposite directions: the monetary authority's actions added to inflationary pressures, whereas the tax cuts reduced inflation in 2001 and 2002.

\section{Robustness Analysis}

In this section we investigate the robustness of the effects of expansionary fiscal policy on investment under several alternative model specifications. The results of these robustness checks are summarized in Table 6 . To get a sense of how the investment response varies quantitatively across model specifications, we report impact and cumulative present value multipliers (calculated as in footnote 12) for each case. 
6.1. Varying $\alpha^{G}$. The elasticity of output to government capital, $\alpha^{G}$, cannot be identified from our observables. For the baseline estimation, we calibrate $\alpha^{G}=0.05$. To determine how sensitive our estimates and inferences are to this parameter, we estimate the model for two alternative cases where $\alpha^{G}=0.001$ and $\alpha^{G}=0.1$. We find that the data cannot distinguish between the three values for $\alpha^{G}$ (see Table 3), as the log marginal data densities in the three cases are virtually identical. The third and third columns of Table 6 show the investment multipliers when $\alpha^{G}=0.001$ and $\alpha^{G}=0.1$. Varying $\alpha^{G}$ affects only the multipliers for government investment. When $\alpha^{G}$ is very small, a government investment shock resembles a non-productive government consumption shock. The more productive government investment is (the larger $\alpha^{G}$ is), the higher the cumulative present value multiplier is, as the returns to investment rapidly increase.

6.2. No Automatic Stabilizers. Because the estimation for the contemporaneous response of income tax rates to output is largely influenced by our priors (see Appendix ??), we check whether our results are sensitive to the estimates of automatic stabilizer coefficients, $\varphi_{K}$ and $\varphi_{L}$. We estimate a version of the model where these parameters are calibrated to zero. The fifth column of Table 6 shows that this substantially affects only the multipliers for government investment. Following a government investment shock, output rises as productivity increases. Automatic stabilizers cause capital and labor taxes to increase as well, dampening the overall effects.

6.3. Standard Calibration of Consumption and Labor Supply Elasticities. Our benchmark estimates of the intertemporal elasticity of substitution $(1 / \gamma)$ and the labor preference parameter $(\kappa)$ differ from the standard values used in the real business cycle literature. We re-estimate the model when these parameters are calibrated to more typical values $(\gamma=\kappa=1)$. Again, this modification has small quantitative effects overall (shown in the last column of Table 6). It raises the present-value government investment multiplier and causes investment to increase on impact following a consumption tax shock.

\section{Concluding Remarks}

This paper studies crowding out by U.S. government debt using a structural DSGE approach. Two contributions to the literature follow. First, we estimate a New Keynesian model with a detailed fiscal specification, which can account for the dynamics between fiscal and monetary policy interactions and fiscal adjustments induced by debt accumulation. Most fiscal instruments are found to respond to debt systematically: When the debt-to-output ratio rises, the government reduces its purchases and transfers and increases income taxes to rein in debt growth. The relatively low estimate for the fraction of non-savers suggests the importance of forward-looking behaviors in explaining the aggregate effects of fiscal policy.

Second, our estimation implies there is no systematic reduced-form relationship between government debt and real interest rates. Whether crowding out by government debt occurs depends on the type of policy innovation that brings forth debt growth. Distortionary fiscal financing and monetary policy are important for gauging the magnitude of the investment and real interest rate responses following a debt expansion. In particular, increases in future capital and labor taxes necessary to offset debt accumulation have a negative impact on 
investment. Also, the responses of the real interest rate and investment can be influenced by how aggressively the central bank stabilizes inflation and output. We demonstrate that reduced form estimates of the relationship between debt and real interest rates depend on the relative magnitudes of the innovations over the estimated horizon. The result helps explain why empirical studies focusing on the relationship between interest rates and debt are often inconclusive.

Our estimation focuses on the post-1983 U.S. sample. Leeper, Plante, and Traum (2010) finds evidence of instability in the estimates of fiscal policy parameters across various sample periods. Davig and Leeper (2009) estimate Markov-switching rules for monetary and fiscal policy from 1949Q1 to 2008Q4 and find multiple regime changes among active and passive monetary and fiscal policies. Confronting these instability issues and accounting for the possibility of passive monetary policy and active fiscal policy in earlier samples is left for future work. 
TABle 1. Prior and Posterior Distributions for Estimated Parameters.

\begin{tabular}{|c|c|c|c|c|c|c|}
\hline \multirow[t]{2}{*}{ Parameters } & \multicolumn{4}{|c|}{ Prior } & \multicolumn{2}{|c|}{ Posterior } \\
\hline & func. & mean & std. & $90 \%$ int. & mean & $90 \%$ int. \\
\hline \multicolumn{7}{|l|}{ Preference and technology } \\
\hline$\gamma$, risk aversion & $G$ & 1.5 & 0.3 & {$[1,2]$} & 2.7 & {$[2.2,3.3]$} \\
\hline$\kappa$, inverse Frisch labor elast. & $G$ & 2 & 0.5 & {$[1.3,2.9]$} & 2.1 & {$[1.4,3]$} \\
\hline $\begin{array}{l}\mu, \text { fraction of non-Ricar. households } \\
\text { Frictions }\end{array}$ & $B$ & 0.3 & 0.1 & {$[0.14,0.48]$} & 0.18 & {$[0.099,0.27]$} \\
\hline$\omega_{w}$, wage stickiness & $B$ & 0.5 & 0.1 & {$[0.34,0.66]$} & 0.69 & {$[0.59,0.79]$} \\
\hline$\omega_{p}$, price stickiness & $B$ & 0.5 & 0.1 & {$[0.34,0.66]$} & 0.82 & {$[0.75,0.88]$} \\
\hline$\psi$, capital utilization & $B$ & 0.6 & 0.15 & {$[0.35,0.85]$} & 0.38 & {$[0.22,0.55]$} \\
\hline$s$, investment adj. cost & $N$ & 6 & 1.5 & {$[3.5,8.5]$} & 7.4 & {$[5.2,9.6]$} \\
\hline$\chi^{w}$, wage partial indexation & $B$ & 0.5 & 0.15 & {$[0.25,0.75]$} & 0.39 & {$[0.19,0.62]$} \\
\hline \multicolumn{7}{|l|}{ Fiscal policy } \\
\hline$\gamma_{G C}$, govt consumption resp to debt & $N$ & 0.15 & 0.1 & {$[-0.01,0.3]$} & 0.17 & {$[0.0051,0.33]$} \\
\hline$\gamma_{G I}$, govt investment resp to debt & $N$ & 0.15 & 0.1 & {$[-0.01,0.3]$} & 0.0033 & {$[-0.11,0.14]$} \\
\hline$\gamma_{K}$, capital tax resp to debt & $N$ & 0.15 & 0.1 & {$[-0.01,0.3]$} & 0.17 & {$[0.028,0.32]$} \\
\hline$\gamma_{L}$, labor tax resp to debt & $N$ & 0.15 & 0.1 & {$[-0.01,0.3]$} & 0.16 & {$[0.021,0.3]$} \\
\hline$\gamma_{Z}$, transfers resp to debt & $N$ & 0.15 & 0.1 & {$[-0.01,0.3]$} & 0.074 & {$[-0.02,0.18]$} \\
\hline$\varphi_{K}$, capital resp. to output & $G$ & 0.75 & 0.35 & {$[0.28,1.4]$} & 0.78 & {$[0.3,1.4]$} \\
\hline \multicolumn{7}{|l|}{ Monetary policy } \\
\hline$\phi_{\pi}$, interest rate resp. to inflation & $N$ & 1.5 & 0.25 & {$[1.1,1.8]$} & 1.9 & {$[1.6,2.3]$} \\
\hline$\phi_{y}$, interest rate resp. to output & $N$ & 0.125 & 0.10 & {$[-0.04,0.3]$} & 0.095 & {$[0.048,0.15]$} \\
\hline $\begin{array}{l}\rho_{r} \text {, lagged interest rate resp. } \\
\text { Serial correl. in disturbances }\end{array}$ & $B$ & 0.5 & 0.2 & {$[0.17,0.83]$} & 0.86 & {$[0.83,0.89]$} \\
\hline$\rho_{a}$, technology & $B$ & 0.5 & 0.2 & {$[0.17,0.83]$} & 0.89 & {$[0.84,0.95]$} \\
\hline$\rho_{b}$, preference & $B$ & 0.5 & 0.2 & {$[0.17,0.83]$} & 0.94 & {$[0.9,0.97]$} \\
\hline$\rho_{i}$, investment & $B$ & 0.5 & 0.2 & {$[0.17,0.83]$} & 0.55 & {$[0.41,0.68]$} \\
\hline$\rho_{w}$, wage markup & $B$ & 0.5 & 0.2 & {$[0.17,0.83]$} & 0.3 & {$[0.15,0.47]$} \\
\hline$\rho_{p}$, price markup & $B$ & 0.5 & 0.2 & {$[0.17,0.83]$} & 0.34 & {$[0.11,0.59]$} \\
\hline$\rho_{G C}$, government consumption & $B$ & 0.5 & 0.2 & {$[0.17,0.83]$} & 0.96 & {$[0.93,0.98]$} \\
\hline$\rho_{G I}$, government investment & $B$ & 0.5 & 0.2 & {$[0.17,0.83]$} & 0.76 & {$[0.64,0.86]$} \\
\hline$\rho_{K}$, capital tax & $B$ & 0.5 & 0.2 & {$[0.17,0.83]$} & 0.89 & {$[0.84,0.95]$} \\
\hline$\rho_{L}$, labor tax & $B$ & 0.5 & 0.2 & {$[0.17,0.83]$} & 0.94 & {$[0.89,0.98]$} \\
\hline$\rho_{C}$, consumption tax & $B$ & 0.5 & 0.2 & {$[0.17,0.83]$} & 0.90 & {$[0.84,0.95]$} \\
\hline$\rho_{Z}$, transfer & $B$ & 0.5 & 0.2 & {$[0.17,0.83]$} & 0.79 & {$[0.7,0.88]$} \\
\hline \multicolumn{7}{|l|}{ Std. of shocks } \\
\hline$\sigma_{a}$, technology & $I G$ & 0.1 & 2 & {$[0.02,0.28]$} & 0.64 & {$[0.56,0.74]$} \\
\hline$\sigma_{b}$, preference & $I G$ & 0.1 & 2 & {$[0.02,0.28]$} & 2.4 & {$[1.9,3.1]$} \\
\hline$\sigma_{m}$, monetary policy & $I G$ & 0.1 & 2 & {$[0.02,0.28]$} & 0.14 & {$[0.13,0.16]$} \\
\hline$\sigma_{i}$, investment & $I G$ & 0.1 & 2 & {$[0.02,0.28]$} & 4.3 & {$[3.6,5.2]$} \\
\hline$\sigma_{w}$, wage markup & $I G$ & 0.1 & 2 & {$[0.02,0.28]$} & 0.27 & {$[0.22,0.33]$} \\
\hline$\sigma_{p}$, price markup & $I G$ & 0.1 & 2 & {$[0.02,0.28]$} & 0.19 & {$[0.16,0.23]$} \\
\hline$\sigma_{G C}$, government consumption & $I G$ & 1 & $\infty$ & {$[0.21,2.8]$} & 2.8 & {$[2.5,3.1]$} \\
\hline$\sigma_{G I}$, government investment & $I G$ & 1 & $\infty$ & {$[0.21,2.8]$} & 4 & {$[3.5,4.5]$} \\
\hline$\sigma_{K}$, capital tax & $I G$ & 1 & $\infty$ & {$[0.21,2.8]$} & 4.2 & {$[3.8,4.7]$} \\
\hline$\sigma_{L}$, labor tax & $I G$ & 1 & $\infty$ & {$[0.21,2.8]$} & 2.3 & {$[2,2.5]$} \\
\hline$\sigma_{C}$, consumption tax & $I G$ & 1 & $\infty$ & {$[0.21,2.8]$} & 3.3 & {$[2.9,3.7]$} \\
\hline$\sigma_{Z}$, transfers & $I G$ & 1 & $\infty$ & {$[0.21,2.8]$} & 2.6 & {$[2.3,3]$} \\
\hline$\sigma_{K L}$, co-movement btw $\mathrm{K}$ and $\mathrm{L}$ taxes & $N$ & 0.2 & 0.1 & {$[0.036,0.36]$} & 0.23 & {$[0.17,0.29]$} \\
\hline
\end{tabular}


TABle 2. Prior and posterior analysis. The top two rows are percentages of prior and posterior draws that lead to crowding out of investment on impact following various fiscal shocks. The bottom two rows are 90-percent intervals of cumulative present value multipliers for prior and posterior draws following various fiscal shocks. Results are based on 30,000 draws from the prior and posterior distributions.

\begin{tabular}{clcccccc}
\hline & & $G^{C} \uparrow$ & $G^{I} \uparrow$ & $\tau^{K} \downarrow$ & $\tau^{L} \downarrow$ & $\tau^{C} \downarrow$ & $Z \uparrow$ \\
\hline \multirow{2}{*}{ Impact } & Prior & $100 \%$ & $44 \%$ & $3 \%$ & $70 \%$ & $60 \%$ & $100 \%$ \\
& Posterior & $100 \%$ & $0 \%$ & $0 \%$ & $83 \%$ & $30 \%$ & $100 \%$ \\
PV Inv. & Prior & $(-1.05,0.042)$ & $(2.38,4.28)$ & $(-1.56,0.66)$ & $(-0.9,0.33)$ & $(-0.53,-0.1)$ & $(-0.98,0.072)$ \\
Multiplier & Posterior & $(-1.52,-0.29)$ & $(0.53,0.99)$ & $(-0.6,-0.16)$ & $(-2.24,3.21)$ & $(-1.15,-0.01)$ & $(-0.96,-0.12)$ \\
\hline
\end{tabular}


TABLE 3. Sensitivity analysis. The table reports posterior means and $90 \%$ credible intervals (in parentheses) for various models. Log-marginal data densities calculated using Geweke's (1999) modified harmonic mean estimator are reported along with Bayes factors relative to the benchmark model. The logmarginal data densities are calculated using a truncation parameter of 0.5.

\begin{tabular}{|c|c|c|c|c|c|}
\hline \multirow[t]{2}{*}{ Key Parameters } & \multicolumn{5}{|c|}{ Models } \\
\hline & $\begin{array}{c}\text { benchmark } \\
\left(\alpha^{G}=0.05\right) \\
\end{array}$ & $\alpha G=0.001$ & $\alpha^{G}=0.1$ & $\varphi_{K}=\varphi_{L}=0$ & $\begin{array}{c}\text { only transfers } \\
\text { adjust to } B\end{array}$ \\
\hline Preference and technology & & & & & \\
\hline$\gamma$, risk aversion & $\begin{array}{c}2.7 \\
(2.2,3.3)\end{array}$ & $\begin{array}{c}2.7 \\
(2.2,3.3)\end{array}$ & $\begin{array}{c}2.7 \\
(2.2,3.3)\end{array}$ & $\begin{array}{c}2.7 \\
(2.2,3.3)\end{array}$ & $\begin{array}{c}2.7 \\
(2.2,3.3)\end{array}$ \\
\hline$\kappa$, inverse Frisch labor elast. & $\begin{array}{c}2.1 \\
(1.4,3)\end{array}$ & $\begin{array}{c}2.1 \\
(1.3,3)\end{array}$ & $\begin{array}{c}2.1 \\
(1.4,3)\end{array}$ & $\begin{array}{c}2.1 \\
(1.3,3)\end{array}$ & $\begin{array}{c}2.1 \\
(1.4,3)\end{array}$ \\
\hline$\mu$, fraction of non-Ricar. households & $\begin{array}{c}0.18 \\
(0.099,0.27)\end{array}$ & $\begin{array}{c}0.18 \\
(0.1,0.28)\end{array}$ & $\begin{array}{c}0.18 \\
(0.1,0.28)\end{array}$ & $\begin{array}{c}0.18 \\
(0.1,0.28)\end{array}$ & $\begin{array}{c}0.2 \\
(0.11,0.3)\end{array}$ \\
\hline Frictions & & & & & \\
\hline$\omega_{w}$, wage stickiness & $\begin{array}{c}0.69 \\
(0.59,0.79)\end{array}$ & $\begin{array}{c}0.69 \\
(0.59,0.79)\end{array}$ & $\begin{array}{c}0.7 \\
(0.59,0.79)\end{array}$ & $\begin{array}{c}0.7 \\
(0.59,0.79)\end{array}$ & $\begin{array}{c}0.69 \\
(0.59,0.79)\end{array}$ \\
\hline$\omega_{p}$, price stickiness & $\begin{array}{c}0.82 \\
(0.75,0.88)\end{array}$ & $\begin{array}{c}0.81 \\
(0.74,0.88)\end{array}$ & $\begin{array}{c}0.82 \\
(0.75,0.88)\end{array}$ & $\begin{array}{c}0.82 \\
(0.74,0.88)\end{array}$ & $\begin{array}{c}0.82 \\
(0.74,0.87)\end{array}$ \\
\hline$\psi$, capital utilization & $\begin{array}{c}0.38 \\
(0.22,0.55)\end{array}$ & $\begin{array}{c}0.38 \\
(0.23,0.55)\end{array}$ & $\begin{array}{c}0.37 \\
(0.22,0.54)\end{array}$ & $\begin{array}{c}0.38 \\
(0.22,0.55)\end{array}$ & $\begin{array}{c}0.39 \\
(0.24,0.55)\end{array}$ \\
\hline$f$, investment adj. cost & $\begin{array}{c}7.4 \\
(5.2,9.6)\end{array}$ & $\begin{array}{c}7.3 \\
(5.2,9.5)\end{array}$ & $\begin{array}{c}7.4 \\
(5.2,9.6)\end{array}$ & $\begin{array}{c}7.3 \\
(5.2,9.6)\end{array}$ & $\begin{array}{c}7.4 \\
(5.2,9.6)\end{array}$ \\
\hline$\chi^{w}$, wage partial indexation & $\begin{array}{c}0.39 \\
(0.19,0.62)\end{array}$ & $\begin{array}{c}0.39 \\
(0.19,0.62)\end{array}$ & $\begin{array}{c}0.38 \\
(0.18,0.61)\end{array}$ & $\begin{array}{c}0.38 \\
(0.18,0.62)\end{array}$ & $\begin{array}{c}0.38 \\
(0.19,0.62)\end{array}$ \\
\hline$\chi^{p}$, price partial indexation & $\begin{array}{c}0.31 \\
(0.13,0.54)\end{array}$ & $\begin{array}{c}0.32 \\
(0.13,0.55)\end{array}$ & $\begin{array}{c}0.3 \\
(0.13,0.54)\end{array}$ & $\begin{array}{c}0.3 \\
(0.13,0.53)\end{array}$ & $\begin{array}{c}0.29 \\
(0.13,0.53)\end{array}$ \\
\hline Fiscal policy & & & & & \\
\hline$\gamma_{G C}$, govt consumption resp to debt & $\begin{array}{c}0.17 \\
(0.0051,0.33)\end{array}$ & $\begin{array}{c}0.16 \\
(0.0045,0.32)\end{array}$ & $\begin{array}{c}0.16 \\
(0.0074,0.32)\end{array}$ & $\begin{array}{c}0.16 \\
(0.0034,0.32)\end{array}$ & - \\
\hline$\gamma_{G I}$, govt investment resp to debt & $\begin{array}{c}0.0033 \\
(-0.11,0.14)\end{array}$ & $\begin{array}{c}-0.0031 \\
(-0.12,0.13)\end{array}$ & $\begin{array}{c}0.0075 \\
(-0.11,0.16)\end{array}$ & $\begin{array}{c}0.0006 \\
(-0.11,0.14)\end{array}$ & - \\
\hline$\gamma_{K}$, capital tax resp to debt & $\begin{array}{c}0.17 \\
(0.028,0.32)\end{array}$ & $\begin{array}{c}0.17 \\
(0.03,0.32)\end{array}$ & $\begin{array}{c}0.17 \\
(0.027,0.32)\end{array}$ & $\begin{array}{c}0.16 \\
(0.017,0.31)\end{array}$ & - \\
\hline$\gamma_{L}$, labor tax resp to debt & $\begin{array}{c}0.16 \\
(0.021,0.3)\end{array}$ & $\begin{array}{c}0.16 \\
(0.023,0.3)\end{array}$ & $\begin{array}{c}0.15 \\
(0.022,0.3)\end{array}$ & $\begin{array}{c}0.15 \\
(0.02,0.3)\end{array}$ & - \\
\hline$\gamma_{Z}$, transfers resp to debt & $\begin{array}{c}0.074 \\
(-0.02,0.18)\end{array}$ & $\begin{array}{c}0.075 \\
(-0.02,0.18)\end{array}$ & $\begin{array}{c}0.07 \\
(-0.02,0.18)\end{array}$ & $\begin{array}{c}0.069 \\
(-0.02,0.18)\end{array}$ & $\begin{array}{c}0.2 \\
(0.15,0.38)\end{array}$ \\
\hline$\varphi_{K}$, capital resp. to output & $\begin{array}{c}0.78 \\
(0.3,1.4)\end{array}$ & $\begin{array}{c}0.78 \\
(0.3,1.4)\end{array}$ & $\begin{array}{c}0.73 \\
(0.3,1.4)\end{array}$ & - & $\begin{array}{c}0.71 \\
(0.29,1.4)\end{array}$ \\
\hline$\varphi_{L}$, labor resp. to output & $\begin{array}{c}0.43 \\
(0.15,0.83)\end{array}$ & $\begin{array}{c}0.43 \\
(0.15,0.83)\end{array}$ & $\begin{array}{c}0.4 \\
(0.15,0.82)\end{array}$ & - & $\begin{array}{c}0.38 \\
(0.14,0.81)\end{array}$ \\
\hline Monetary policy & & & & & \\
\hline$\phi_{\pi}$, interest rate resp. to inflation & $\begin{array}{c}1.9 \\
(1.6,2.3)\end{array}$ & $\begin{array}{c}1.9 \\
(1.6,2.3)\end{array}$ & $\begin{array}{c}1.9 \\
(1.6,2.2)\end{array}$ & $\begin{array}{c}1.9 \\
(1.6,2.3)\end{array}$ & $\begin{array}{c}1.9 \\
(1.6,2.3)\end{array}$ \\
\hline$\phi_{y}$, interest rate resp. to output & $\begin{array}{c}0.095 \\
(0.048,0.15)\end{array}$ & $\begin{array}{c}0.093 \\
(0.047,0.15)\end{array}$ & $\begin{array}{c}0.095 \\
(0.051,0.15)\end{array}$ & $\begin{array}{c}0.094 \\
(0.05,0.15)\end{array}$ & $\begin{array}{c}0.093 \\
(0.048,0.15)\end{array}$ \\
\hline$\rho_{r}$, lagged interest rate resp. & $\begin{array}{c}0.86 \\
(0.83,0.89) \\
\end{array}$ & $\begin{array}{c}0.86 \\
(0.83,0.89) \\
\end{array}$ & $\begin{array}{c}0.86 \\
(0.83,0.89) \\
\end{array}$ & $\begin{array}{c}0.86 \\
(0.83,0.89)\end{array}$ & $\begin{array}{c}0.86 \\
(0.83,0.89) \\
\end{array}$ \\
\hline $\begin{array}{l}\text { model comparison } \\
\text { log marginal data density } \\
\text { Bayes Factor rel. to benchmark }\end{array}$ & $\begin{array}{c}-63.45 \\
1 \\
\end{array}$ & $\begin{array}{c}-63.65 \\
\exp [0.2]\end{array}$ & $\begin{array}{c}-63.30 \\
\exp [-0.15] \\
\end{array}$ & $\begin{array}{c}-64.17 \\
\exp [0.72] \\
\end{array}$ & $\begin{array}{c}-66.44 \\
\exp [2.99] \\
\end{array}$ \\
\hline
\end{tabular}


TABLE 4. Reduced-form regressions from simulated data using the mean posterior parameter estimates. Estimates are for $\beta_{1}$ from the OLS regression $x_{t}=\beta_{0}+\beta_{1} \hat{s}_{t}^{b}+\epsilon_{t}$, where $x_{t}$ is either the one-period real interest rate $\hat{r}_{t}$ or the ten-year real interest rate $\hat{r}_{t}^{10}$. The table reports the mean and $90 \%$ interval (in parenthesis) from 500 simulated data series from the posterior mean.

\begin{tabular}{c|cccc}
\hline $\begin{array}{c}\text { Dependent } \\
\text { variable }\end{array}$ & $\begin{array}{c}\text { All } \\
\text { shocks }\end{array}$ & $\begin{array}{c}G^{C} \\
\text { shocks }\end{array}$ & $\begin{array}{c}\tau^{L} \\
\text { shocks }\end{array}$ & $\begin{array}{c}\text { Monetary } \\
\text { shocks }\end{array}$ \\
\hline$\hat{r}_{t}$ & -0.0005 & 0.0008 & 0.0 & 0.0083 \\
& $(-0.015,0.012)$ & $(-0.0002,0.002)$ & $(-0.0003,0.0002)$ & $(-0.0053,0.025)$ \\
$\hat{r}_{t}^{10}$ & -0.02 & 0.02 & -0.006 & 0.02 \\
& $(-0.21,0.11)$ & $(-0.005,0.04)$ & $(-0.009,-0.003)$ & $(-0.02,0.07)$ \\
\hline
\end{tabular}

TABLE 5. Reduced-form regressions from the estimated historical innovations. Estimates are for $\beta_{1}$ from the OLS regression $x_{t}=\beta_{0}+\beta_{1} \hat{s}_{t}^{b}+\epsilon_{t}$, where $x_{t}$ is either the one-period real interest rate $\hat{r}_{t}$ or the ten-year real interest rate $\hat{r}_{t}^{10}$. The table reports the mean and $90 \%$ interval (in parentheses) from the posterior distribution of parameter estimates.

\begin{tabular}{c|cc}
\hline & \multicolumn{2}{|c}{ Dependent variable } \\
& $\hat{r}_{t}$ & $\hat{r}_{t}^{10}$ \\
\hline$\hat{\beta}_{1}$ & 0.0132 & 0.0269 \\
& $(0.0113,0.0151)$ & $(-0.0045,0.0614)$ \\
\hline
\end{tabular}

TABLE 6. Robustness checks for the short- and long-run effects of expansionary fiscal policy on investment. The rows display impact and cumulative present value (PV) multipliers for investment following various shocks. PV multiplier calculations are described in footnote 12.

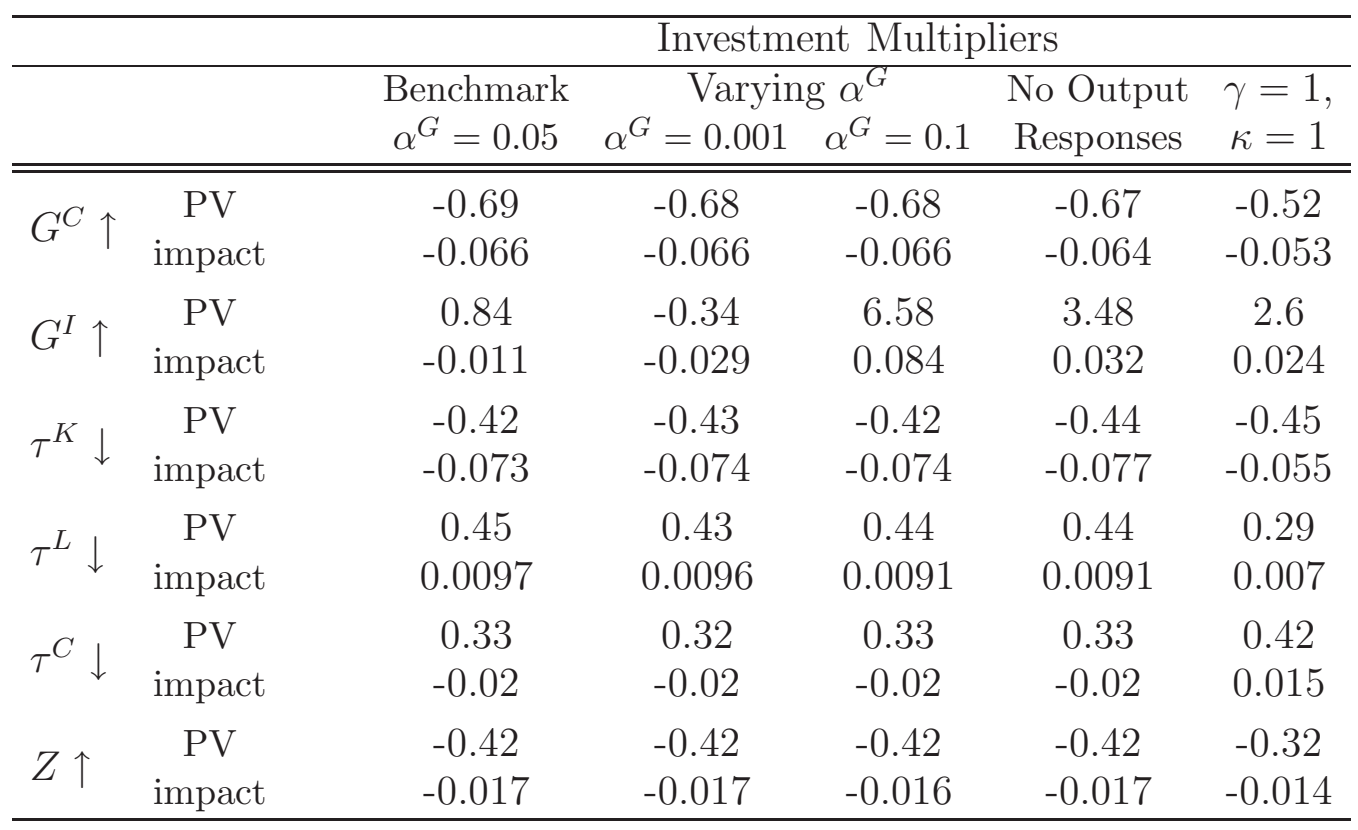



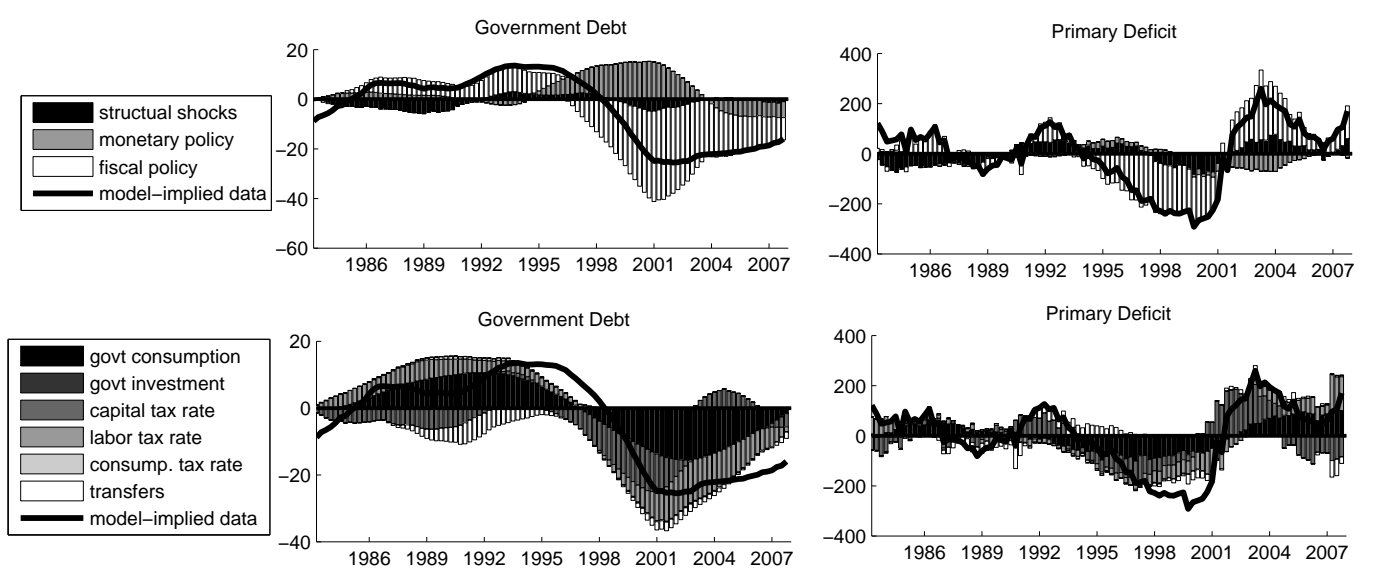

FigURE 1. Historical variance decomposition for model-implied federal debt and primary deficits. Top row: breakdown by fiscal, monetary, and all other shocks; bottom row: breakdown among fiscal shocks. The main four fiscal shocks are government consumption, capital tax, labor tax, and transfers shocks, in the order of the darkest to lightest shade. Units for the $\mathrm{y}$-axis are percentage deviation from the steady-state path.
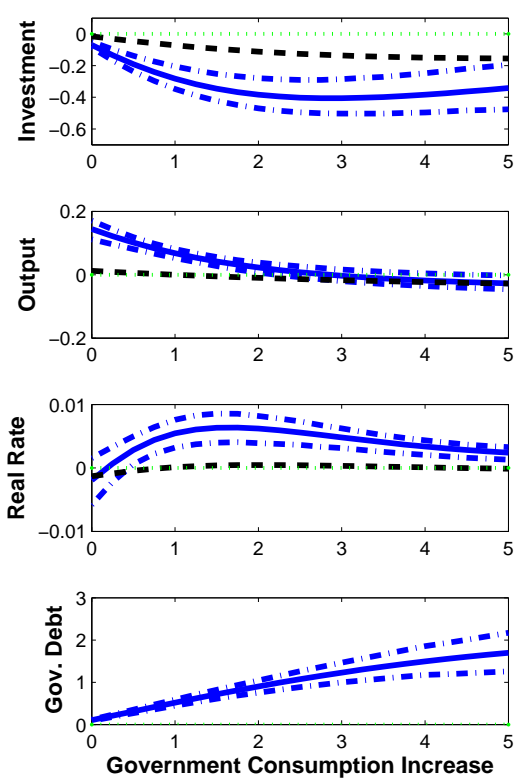
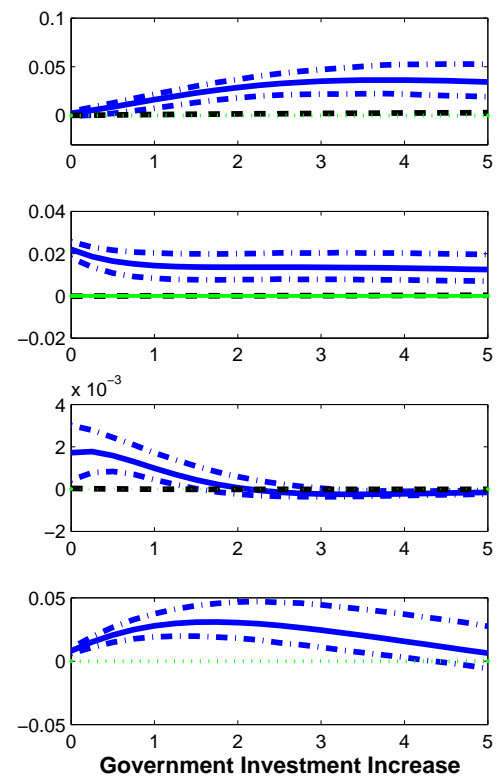
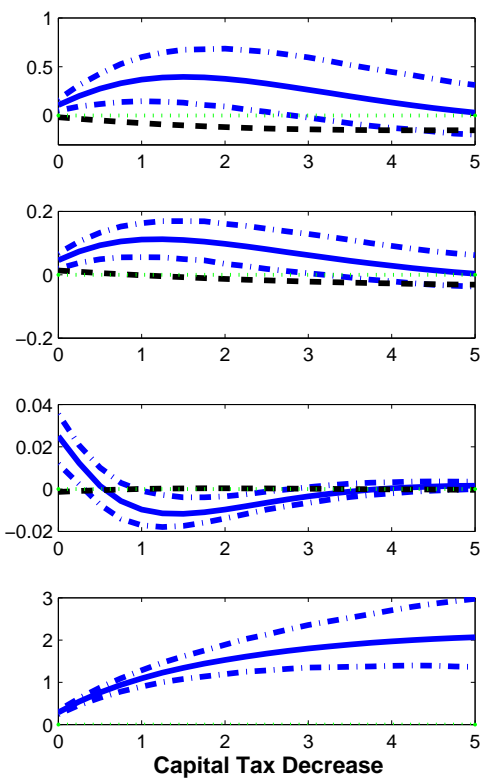

FIGURE 2. Impulse responses for policy shocks of one standard deviation. Solid lines: estimated mean responses; dotted-dashed lines: 90-percent pointwise probability intervals; dashed lines: responses due to distortionary fiscal financing. The y-axis measures percentage deviation from the steady state. The $\mathrm{x}$-axis is in years after a shock. 

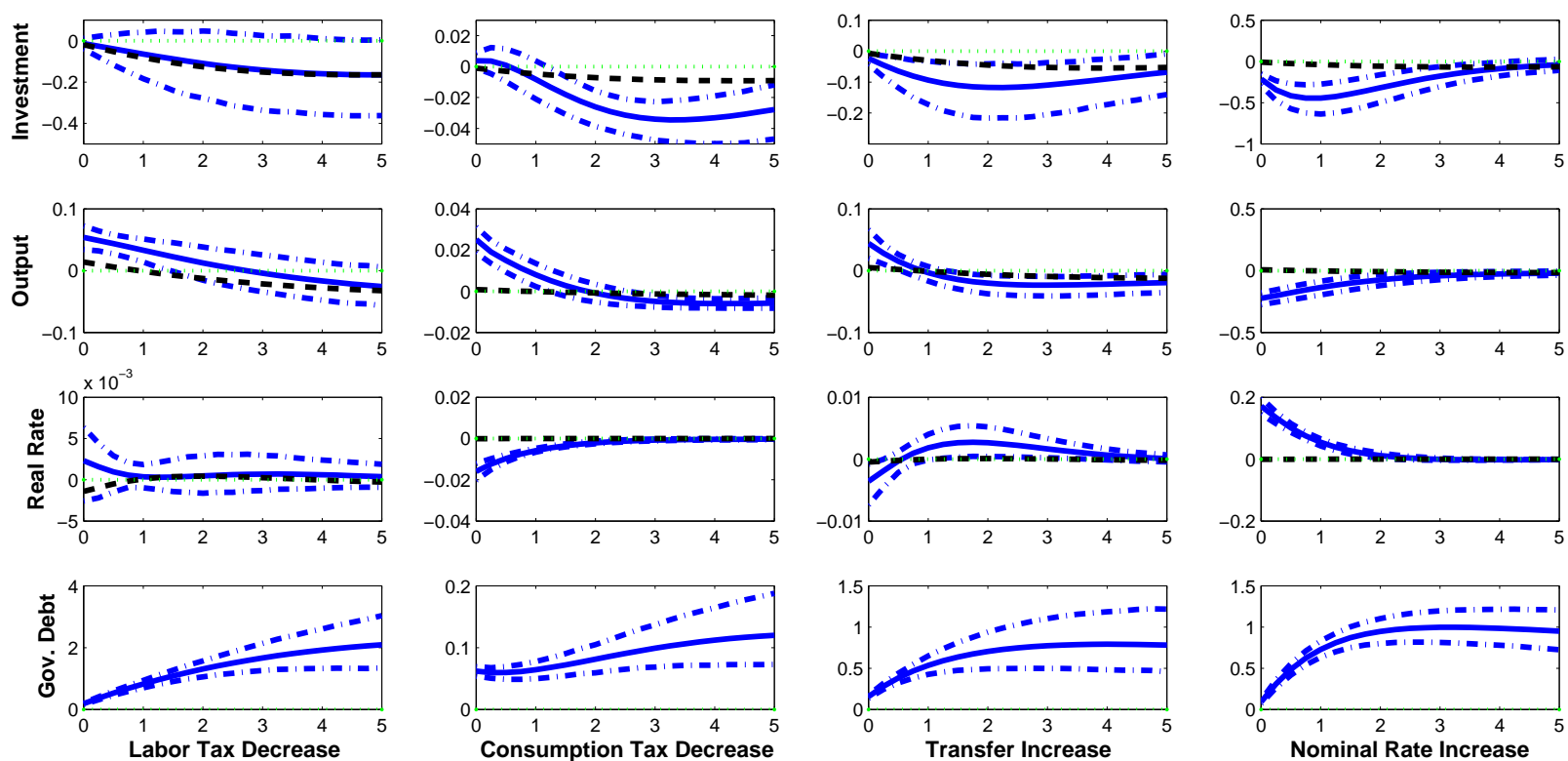

FigURE 3. Impulse responses for policy shocks of one standard deviation. Solid lines: estimated mean responses; dotted-dashed lines: 90-percent pointwise probability intervals; dashed lines: responses due to distortionary fiscal financing. The y-axis measures percentage deviation from the steady state. The $\mathrm{x}$-axis is in years after a shock. 

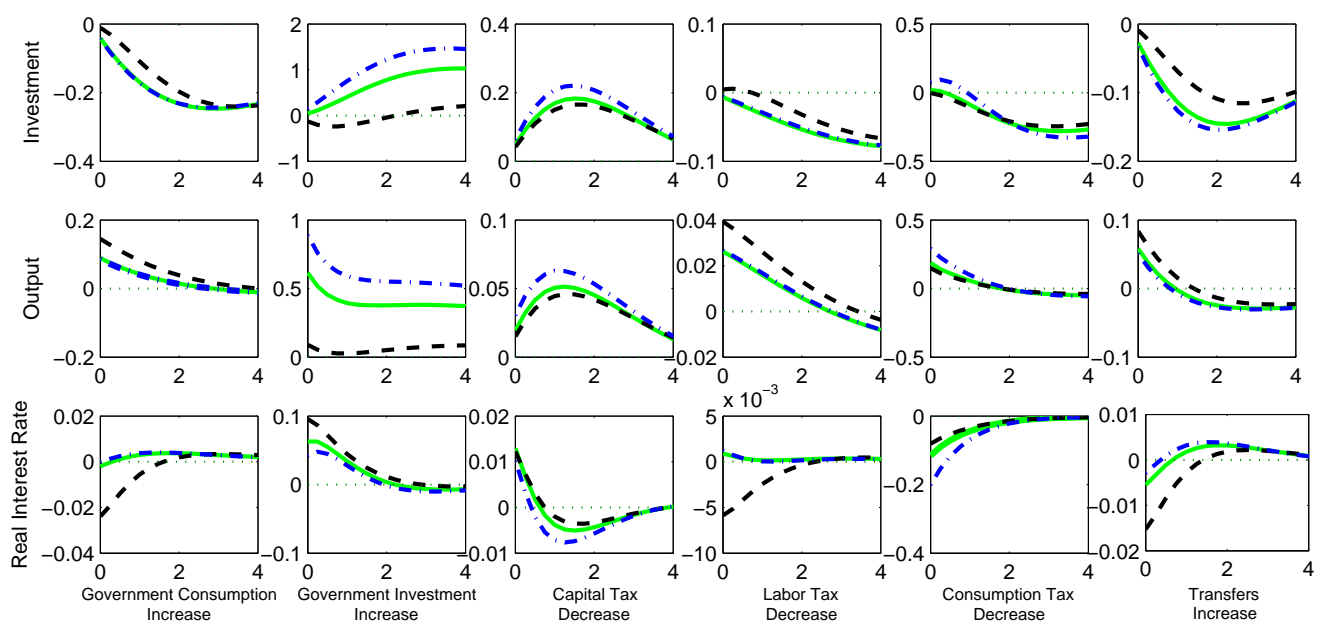

FIGURE 4. Impulse responses under various response magnitudes to inflation. Dashed lines: $\phi_{\pi}=1.05$; solid lines: $\phi_{\pi}=1.70$; dotted dashed lines: $\phi_{\pi}=2.5$. The $\mathrm{y}$-axis is in percentage deviations from the steady state. The $\mathrm{x}$-axis measures years after a shock. 

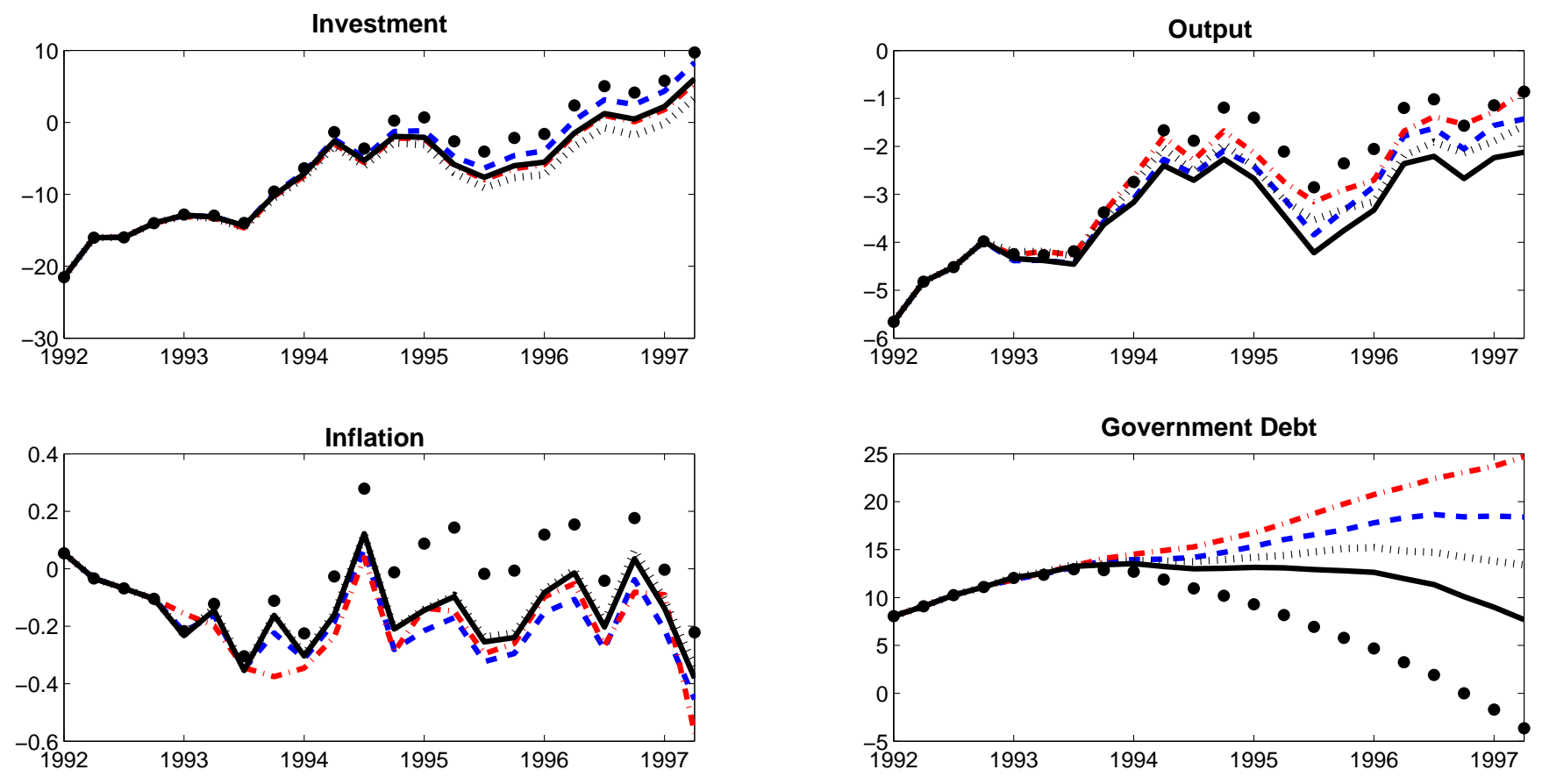

Figure 5. Counterfactual exercise: tax increase in the 1990s. Solid lines: data (observed or model-implied) conditional on the estimated sequence of all shocks; dashed lines: capital and labor tax shocks turned off; dotted lines: fiscal expenditure shocks turned off; dotted-dashed lines: all fiscal policy shocks turned off; dots: monetary policy shock turned off. 

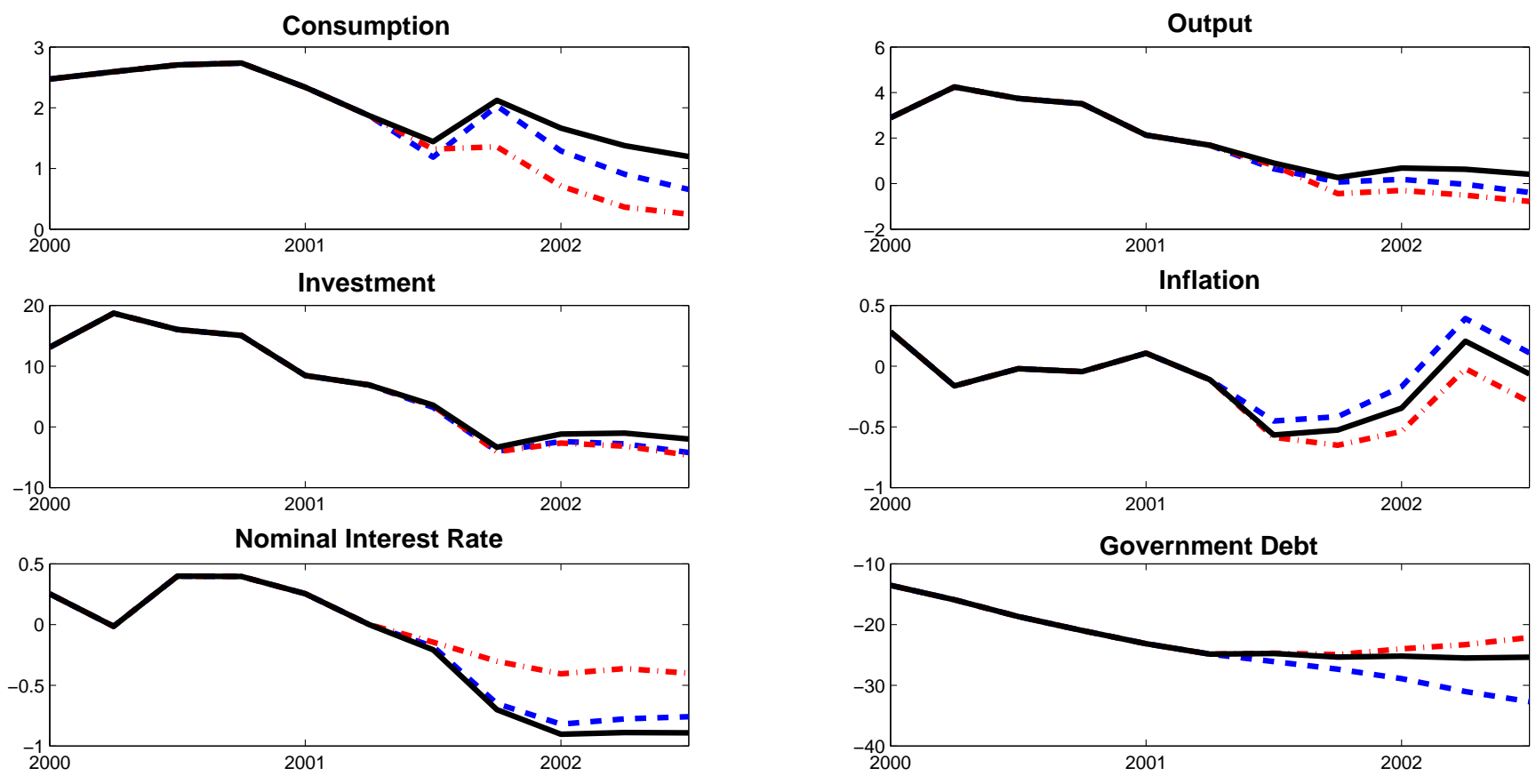

Figure 6. Counterfactual exercise: tax cuts in 2001 and 2002. Solid lines: data (observed or model-implied) conditional on the estimated sequence of all shocks; dashed lines: capital and labor tax shocks turned off; dotteddashed lines: monetary policy shock turned off. 


\section{REFERENCES}

Alvarez-Lois, P., R. Harrison, L. Piscitelli, and A. Scott (2008): "On the application and use of DSGE models," Journal of Economic Dynamics and Control, 32(8), $2428-2452$.

An, S., And F. Schorfheide (2007): "Bayesian Analysis of DSGE Models," Econometric Reviews, 26(2-4), 113-172.

Barro, R. J. (1974): "Are Government Bonds Net Wealth?," Journal of Political Economy, $82(6), 1095-1117$.

Barth, J. R., G. Iden, And F. S. Russek (1984): "Do Federal Deficits Really Matter?," Contemporary Economic Policy, 3(1), 79-95.

Basu, S., And J. G. Fernald (1995): "Are Apparent Productive Spillovers a Figment of Specification Error?," Journal of Monetary Economics, 36(1), 165-188.

Baxter, M., And R. G. King (1993): "Fiscal Policy in General Equilibrium," American Economic Review, 83(3), 315-334.

Bernheim, B. D. (1989): "A Neoclassical Perspective on Budget Deficits," Journal of Economic Perspectives, 3(2), 55-72.

Bilbite, F. O., A. Meier, And G. Mueller (forthcoming): "What Accounts for the Change in U.S. Fiscal Policy Transmission?," Journal of Money, Credit and Banking.

Blanchard, O. J. (1985): "Debts, Deficits, and Finite Horizons," Journal of Political Economy, 93(2), 223-247.

Bouakez, H., and N. Rebei (2007): "Why Does Private Consumption Rise After A Government Spending Shock?," Canadian Journal of Economics, 40(3), 954-979.

Brunner, K., And A. H. Meltzer (1972): "Money, Debt, and Economic Activity," Journal of Political Economy, 80(5), 951-977.

Buiter, W. H., And J. ToBin (1980): "Fiscal and Monetary Policies, Capital Formation, and Economic Activity," in The Government and Capital Formation, ed. by G. Von Furstenberg, pp. 73-151. Ballinger Publishing Company, Cambridge, MA.

Calvo, G. A. (1983): "Staggered Prices in a Utility Maxmimizing Model," Journal of Monetary Economics, 12(3), 383-398.

Campbell, J. Y., And N. G. Mankiw (1989): "Consumption, Incomes, and Interest Rates: Reinterpreting the Time Series Evidence," in NBER Macroeconomics Annual 1989, ed. by O. J. Blanchard, and S. Fischer, vol. 4, pp. 185-216. MIT Press, Cambridge, MA.

Canova, F. (2009): "Bridging Cyclical DSGE Models and the Raw Data," Manuscript, Centre de Recerca en Economia Internacional.

Chang, Y., T. Doh, And F. Schorfheide (2007): "Non-stationary Hours in a DSGE Model," Journal of Money, Credit and Banking, 39(6), 1357-1373.

Christiano, L. J., M. Eichenbaum, and C. L. Evans (2005): "Nominal Rigidities and the Dynamic Effects of a Shock to Monetary Policy," Journal of Political Economy, $113(1), 1-45$.

Coenen, G., And R. Straub (2005): "Does Government Spending Crowd In Private Consumption? Theory and Empirical Evidence for the Euro Area," International Finance, $8(3), 437-470$.

Colciago, A. (2007): "Rule of Thumb Consumers Meet Sticky Wages," Munich Personal RePEc Archive Working Paper No. 3756.

Congressional Budget Office (2009): The Long-Term Budget Outlook. Washington, D.C., June. 
Davig, T., And E. M. Leeper (2006): Fluctuating Macro Policies and the Fiscal Theory, NBER Macroeconomics Annual 2006. MIT Press, Cambridge.

(2009): "Monetary-Fiscal Policy Interactions and Fiscal Stimulus," National Bureau of Economic Research Working Paper No. 15133.

Del Negro, M., F. Schorfheide, F. Smets, and R. Wouters (2007): "On the Fit and Forecasting Performance of New Keynesian Models," Journal of Business and Economic Statistics, 25(2), 123-162.

Dixit, A. K., And J. E. Stiglitz (1977): "Monopolistic Competition and Optimum Product Diversity," American Economic Review, 67(3), 297-308.

Domar, E. D. (1944): "The "Burden of the Debt" and the National Income," American Economic Review, 34(4), 798-827.

Elmendorf, D. W., and N. G. Mankiw (1999): "Government Debt," in Handbook of Macroeconomics, ed. by J. B. Taylor, and M. Woodford, vol. 1C, pp. 1615-1669. Elsevier Science, Amsterdam.

Engen, E. M., and R. G. Hubbard (2005): "Federal Government Debt and Interest Rates," in NBER Macroeconomics Annual 2004, ed. by M. Gertler, and K. Rogoff. MIT Press, Cambridge, MA.

Erceg, C. J., L. Guerrieri, and C. J. Gust (2005): "Expansionary Fiscal Shocks and the Trade Deficit," International Finance, 8(3), 363-397.

Evans, P., And G. Karras (1994): "Are Government Activities Productive? Evidence from a Panel of U.S. States," Review of Economic and Statistics, 76(1), 1-11.

Fernandez-Villaverde, J., P. Guerron-Quintana, and J. F. Rubio-Ramirez (2010): "The New Macroeconometrics: A Bayesian Approach," in The Oxford Handbook of Applied Bayesian Analysis, ed. by A. O'Hagan, and M. West. Oxford University Press.

Fernandez-Villaverde, J., J. F. Rubio-Ramirez, T. J. Sargent, and M. W. WATson (2007): "ABCs (and Ds) of Understanding VARs," American Economic Review, 97(3), 1021-1026.

Forni, L., L. Monteforte, and L. Sessa (2009): "The General Equilibrium Effects of Fiscal Policy: Estimates for the Euro Area," Journal of Public Economics, 93(3-4), $559-585$.

Freedman, C., M. Kumhof, D. Laxton, D. Muir, and S. Mursala (2009): "Fiscal Stimulus to the Rescue? Short-Run Benefits and Potential Long-Run Costs of Fiscal Deficits," International Monetary Fund Working Paper No. 255.

Gale, W. G., and P. R. Orszag (2003): "The Economic Effects of Long-Term Fiscal Discipline," Urban-Brookings Tax Policy Center Discussion Paper No. 8.

- (2004): Budget Deficits, National Saving, and Interest Rates, vol. 35(2004-2) of Brookings Papers on Economic Activity. Brookings Institution Press.

Gali, J., J. D. Lopez-Salido, and J. VAlles (2007): "Understanding the Effects of Government Spending on Consumption," Journal of the European Economic Association, 5(1), 227-270.

Geweke, J. (1999): "Using Simulation Methods for Bayesian Econometric Models: Inference, Development, and Communication," Econometric Reviews, 18(1), 1-73.

Greenwood, J., Z. Hercowitz, and P. Krusell (1997): "Long Run Implications of Investment-Specific Technological Change," American Economic Review, 87(3), 342-362. 
(2000): "The Role of Investment-Specific Technological Change in the Business Cycle," European Economic Review, 44(1), 91-115.

Guvenen, F. (2006): "Reconciling Conflicting Evidence on the Elasticity of Intertemporal Substitution: A Macroeconomic Perpsective," Journal of Monetary Economics, 53(7), $1451-1472$.

Iwata, Y. (2009): "Fiscal Policy in an Estimated DSGE Model of the Japanese Economy: Do Non-Ricardian Households Explain All?," Economic and Social Research Institute Discussion Paper Series No. 219.

Jones, J. B. (2002): "Has Fiscal Policy Helped Stabilize the Postwar U.S. Economy?," Journal of Monetary Economics, 49(4), 709-746.

Kamps, C. (2004): The Dynamic Macroeconomic Effects of Public Capital. Springer, Berlin, Germany.

KIM, J. (2000): "Constructing and Estimating a Realistic Optimizing Model of Monetary Policy," Journal of Monetary Economics, 45(2), 329-359.

Kohn, D. L. (1995): Inflation Indicators and Inflation Policy: Comment, NBER Macroeconomics Annual 1995. MIT Press, Cambridge, MA.

Kumhof, M., And D. Laxton (2007): "A Party Without a Hangover? On the Effects of U.S. Government Deficits," International Monetary Fund Working Paper 07/202.

Laubach, T. (2009): "New Evidence on the Interest Rate Effects of Budget Deficits and Debt," Journal of European Economic Association, 7(4), 858-885.

LeEper, E. M. (1991): "Equilibria Under 'Active' and 'Passive' Monetary and Fiscal Policies," Journal of Monetary Economics, 27(1), 129-147.

Leeper, E. M., M. Plante, and N. Traum (2010): "Dynamics of Fiscal Financing in the United States," Journal of Econometrics, 156(2), 304-321.

LeEper, E. M., And C. A. Sims (1994): Toward a Modern Macroeconomic Model Usable for Policy Analysis, NBER Macroeconomics Annual 1994. MIT Press, Cambridge, MA.

LeEPer, E. M., AND S.-C. S. YANG (2008): "Dynamic Scoring: Alternative Financing Schemes," Journal of Public Economics, 92(1-2), 159-182.

Leland, S. E. (1944): "Management of the Public Debt After the War," American Economic Review, 34(2, suppl.), 89-132.

Lopez-Salido, J. D., And P. Rabanal (2006): "Government Spending and Consumption-Hours Preferences," "La Caixa" Working Paper Series No. 02/2006.

Ludvigson, S. (1996): "The Macroeconomic Effects of Government Debt in a Stochastic Growth Model," Journal of Monetary Economics, 38(1), 25-45.

Mankiw, N. G. (2000): "The Savers-Spenders Theory of Fiscal Policy," American Economic Review, 90(2), 120-125.

Modigliani, F. (1961): "Long-Run Implications of Alternative Fiscal Policies and the Burden of the National Debt," The Economic Journal, 71(284), 730-755.

Pereira, A. M., and R. F. De Frutos (1999): "Public Capital Accumulation and Private Sector Performance," Journal of Urban Economics, 46(2), 300-322.

Perotti, R. (2005): "Estimating the Effects of Fiscal Policy in OECD Countries," Centre for Economic Policy Research Discussion Paper 4842.

Ratto, M., W. Roeger, and J. IN'T Veld (2009): "QUEST III: An Estimated OpenEconomy DSGE Model of the Euro Area with Fiscal and Monetary Policy," Economic Modeling, 26(1), 222-233. 
Schmitt-Grohe, S., And M. Uribe (2004): "Optimal Operational Monetary Policy in the Christiano-Eichenbaum-Evans Model of the U.S. Business Cycle," National Bureau of Economic Research Working Paper No. 10724.

- (2008): "What's 'News' in Business Cycles?," National Bureau of Economic Research Working Paper No. 14215.

Sims, C. A. (2001): "Solving Linear Rational Expectations Models," Journal of Computational Economics, 20(1-2), 1-20.

Smets, F., And R. Wouters (2003): "An Estimated Dynamic Stochastic General Equilibrium Model of the Euro Area," Journal of the European Economic Association, 1(5), $1123-1175$.

- (2007): "Shocks and Frictions in U.S. Business Cycles: A Bayesian DSGE Approach," American Economic Review, 97(3), 586-606.

Smetters, K. A. (1999): "Ricardian Equivalence: Long-Run Leviathan," Journal of Public Economics, 73(3), 395-421.

TAYlor, J. B. (1993): "Discretion versus Policy Rules in Practice," Carnegie-Rochester Conference Series on Public Policy, 39(1), 195-214.

Tobin, J. (1969): "A General Equilibrium Approach to Monetary Theory," Journal of Money, Credit and Banking, 1(1), 15-29.

Uhlig, H. (2010): "Some Fiscal Calculus," American Economic Review: Papers and Proceedings, 100(2), 1-5.

Wallich, H. C. (1946): "Debt Management as an Instrument of Economic Policy," American Economic Review, 36(3), 292-310.

YAnG, S.-C. S. (2005): "Quantifying Tax Effects Under Policy Foresight," Journal of Monetary Economics, 52(8), 1557-1568.

Zubairy, S. (2009): "On Fiscal Multipliers: Estimates from a Medium Scale DSGE Model," Manuscript, Duke University. 


\section{Appendix A. Data Description}

Unless otherwise noted, the following data are from the National Income and Product Accounts Tables released by the Bureau of Economic Analysis. All data in levels are nominal values. Nominal data are converted to real values by dividing by the GDP deflator for personal consumption expenditures (Table 1.1.4, line 2).

Consumption. Consumption, $C$, is defined as total personal consumption expenditures (Table 1.1.5, line 2).

Investment. Investment, $I$, is defined as gross private domestic investment (Table 1.1.5, line 7). Note that we define real investment by dividing investment by the GDP deflator for private investment (Table 1.1.4, line 7).

Consumption Tax Revenues. The consumption tax revenues, $T^{c}$, include excise taxes and customs duties (Table 3.2, lines 5 and 6).

Consumption Tax Rates. The average consumption tax rate is defined as

$$
\tau^{C}=\frac{T^{c}}{C-T^{c}-T_{s}^{c}},
$$

where $T_{s}^{c}$ is state and local sales taxes (Table 3.3, line 12).

Capital and Labor Tax Rates. Following Jones (2002), first the average personal income tax rate is computed:

$$
\tau^{p}=\frac{I T}{W+P R I / 2+C I},
$$

where IT is personal current tax revenues (Table 3.2, line 3), $W$ is wage and salary accruals (Table 1.12 line 3), PRI is proprietors' income (Table 1.12, line 3), and $C I$ is capital income. Capital income is defined as rental income (Table 1.12, line 12), corporate profits (Table 1.12, line 13), interest income (Table 1.12 line 18), and PRI/2.

The average labor income tax rate is computed as:

$$
\tau^{L}=\frac{\tau^{p}(W+P R I / 2)+C S I}{E C+P R I / 2},
$$

where CSI is contributions for government social insurance (Table 3.2, line 11) and EC is compensation of employees (Table 1.12, line 2). The average capital income tax rate is calculated as:

$$
\tau^{K}=\frac{\tau^{p} C I+C T}{C I+P T}
$$

where $C T$ is taxes on corporate income (Table 3.2, line 7) and $P T$ is property taxes (Table 3.3 , line 8).

Government Expenditure. Government expenditure, $G^{C}$, is defined as government consumption expenditure (Table 3.2, line 20), government investment for defense (Table 3.9.5, line 13), and government net purchases of non-produced assets (Table 3.2, line 43), minus government consumption of fixed capital (Table 3.2, line 44). 
Government Investment. Government investment, $G^{I}$, is defined as government investment for non-defense (Table 3.9.5, line 18).

Transfers. Transfers, TR, are defined as net current transfers, net capital transfers, and subsidies (Table 3.2, line 31), minus the tax residual. Net current transfers are defined as current transfer payments (Table 3.2, line 21) minus current transfer receipts (Table 3.2, line 15). Net capital transfers are defined as capital transfer payments (Table 3.2, line 42) minus capital transfer receipts (Table 3.2, line 38). The tax residual is defined as current tax receipts (Table 3.2, line 2), contributions for government social insurance (Table 3.2, line 11), income receipts on assets (Table 3.2, line 12), and the current surplus of government enterprises (Table 3.2, line 18), minus total tax revenue, $T$ (consumption, labor, and capital tax revenues).

Hours Worked. Hours worked are constructed from the following variables:

$\boldsymbol{H}$ : the index for nonfarm business, all persons, average weekly hours duration, $1992=$ 100, seasonally adjusted (from the Department of Labor).

$\boldsymbol{E} \boldsymbol{m p}$ : civilian employment for sixteen years and over, measured in thousands, seasonally adjusted (from the Department of Labor, Bureau of Labor Statistics, CE16OV). The series is transformed into an index where 1992Q3 $=100$.

Hours worked are then defined as

$$
N=\frac{H * E m p}{100} .
$$

Wage Rate. The wage rate is defined as the index for hourly compensation for nonfarm business, all persons, $1992=100$, seasonally adjusted (from the U.S. Department of Labor).

Inflation. The gross inflation rate is defined using the GDP deflator for personal consumption expenditures (Table 1.1.4, line 2).

Interest Rate. The nominal interest rate is defined as the average of daily figures of the Federal Funds Rate (from the Board of Governors of the Federal Reserve System).

Definitions of Observable Variables. The observable variable $X$ is defined by making the following transformation to variable $x$ :

$$
X=\ln \left(\frac{x}{\text { Popindex }}\right) * 100,
$$

where

Popindex: index of Pop, constructed such that 1992Q3 = 1;

Pop: Civilian noninstitutional population in thousands, ages 16 years and over, seasonally adjusted (from the Bureau of Labor Statistics).

$x=$ consumption, investment, hours worked, government spending, government investment, capital tax revenues, consumption tax revenues, labor tax revenues, and transfers. The real wage rate is defined in the same way, except that it is not divided by the total population. 